\title{
Biocommunication of Unicellular and Multicellular Organisms
}

The biosemiotic categorization of rule-governed sign-mediated interactions within and between bacteria, fungi and plants

\section{Günther Witzany}

telos - Philosophische Praxis

Vogelsangstraße 18c, A-5111-Bürmoos, Austria

witzany@sbg.at

\begin{abstract}
Far from being mechanistic interactions, communication processes within and between organisms are sign-mediated interactions. Such interactions are the precondition for all cooperation and coordination between at least two biological agents such as organisms, organs, tissues, cells and even subcellular components. In most cases these communication processes are of a fine-tuned interconnected structure within a highly sophisticated hierarchical order. Signs of biocommunicative processes in most cases are chemical molecules. The signs that are used in a great variety of signaling processes follow syntactic, pragmatic and semantic rules. These three levels of semiotic rules are
\end{abstract}

\begin{abstract}
helpful tools in the investigation of the communication processes of unicellular and multicellular organisms. This article demonstrates a coherent biosemiotic categorization of communication processes found in the kingdoms of bacteria, fungi and plants. The investigation further shows that, apart from biotic sign use, a common trait is to interpret abiotic influences as indicators to generate appropriate adaptational behavior.
\end{abstract}

Keywords: communicative competences of bacteria, fungi and plants;

\section{Introduction}

Until the last decade of the twentieth century the interactions within and between organisms were investigated in a great variety of biological disciplines by the assumption of rather mechanistic stimulusreaction patterns, which in principle can be reconstructed by formalisable procedures (i.e. algorithms) expressed in terms like 'machinery', 'apparatus', 'mechanism', etc. In the last decade it has become absolutely clear that organisms interact by using signals as signs according to combinatorial rules (syntax), contextual rules (pragmatic) and content-specific rules (semantic) which cannot be reduced to one another but are crucial for successful communication processes and cannot be objectified sufficiently by the formalisable procedures proposed by mathematical theories of biology.

Throughout this article it is demonstrated that organization and coordination of organism behavior depend on successful communication. If one level of rules is deformed, damaged, or not completed by the transmitting or the receiving organism or interferences within the information transmitter-medium, communication may even fail, with fatal consequences for the organisms. Originally it seemed that communication processes were limited to simple signal exchange but we are now aware that this is the exception, and from bacterial communication processes to fungi and plants different levels of rulegoverned, sign-mediated interactions must function in a parallel and continuous way. This often includes the mixed use of different signaling levels in gaseous, aqueous, crystallized or even tactile types. This means that even behavioral patterns may serve as signs (as icons, indices or symbols). 
Biocommunication from the very beginning of life is a type of complex interaction and it opens appropriate behavioral patterns to adapt to nearly all circumstances of the planetary biosphere.

In contrast with theoretical investigations this contribution will demonstrate the practical applications of a three-leveled biosemiotics. The theoretical investigations I have outlined in great detail in other publications (Witzany 1993, 2000, 2006a) in which I tried to prevent the metaphysical and quasimetaphysical problems inherent in positivistic, holistic, ontological, information-theoretic, system-theoretic and similar objectivistic positions. Pars pro toto may serve as a trial to define 'information', which was thought to be the key term for all scientific investigations on language and communication processes. All attempts during the twentieth century to get a useful definition of 'information' within theoretical and formalisable procedures such as information-theory, cybernetics and related system-theoretical approaches or even semantics or onto-semantics failed to lead to both a coherent understanding and an explanation of an essential procedure common to all communication processes: how it is possible to make the move from a state of private consciousness to a state of mutual agreement and cooperation. I do not want to reproduce here the arguments I have outlined in several articles on developments in the theory of sciences discourse of the twentieth century with its paradigmatic positions of the 'linguistic turn' and the 'pragmatic turn'. As we know today, the latter was able to solve these problems in replacing the (Kantian) solus ipse subject of knowledge by an intersubjective-communicative subject of knowledge. Pragmatic turn thinkers demonstrated that a purely linguistic (syntactic/semantic) or formalistic (i.e. algorithms) analysis of utterances is not able to consider the illocutionary acts performed by interacting subjects, because these analyses are not able to find or even imagine the rules which govern pragmatic contexts of interactions (Witzany 1993, 1995, 1998, 2002, 2003, 2005b). This becomes a serious problem e.g. for bioinformatics in identifying a variety of RNA-silencing processes with different translational products (proteins) from the identical DNA data-set.

In a first step this article on practical applications of a three-leveled biosemiotics will show some examples of biocommunicative processes, i.e. sign-mediated interactions within and between bacterial, fungal and plant organisms which are governed by semiotic rules at three levels (syntax, pragmatics, semantics). Syntactic rules regulate the combinatorial patterns of signs, pragmatic rules determine the (situational) context specificity a sign-using individual is involved and semantic rules determine the content specificity, i.e. the meaning function which is crucial within interpretation processes. Above all we must keep in mind that in life processes there are always sign-using individuals which generate, combine, recombine, change signs in communicative actions. I therefore term communication-processes rulegoverned sign-mediated interactions between cellular components, cells, tissues, organs and/or organisms.

Million of years ago
$\begin{array}{ll}3800 & \text { prokaryotic microfossils (bacteria, archaea) } \\ 1200 & \text { protoctist fossils (unicellular eukaryotes) } \\ 750 & \text { animal fossils } \\ 450 & \text { fungus fossils } \\ 350 & \text { plant fossils }\end{array}$

Figure 1: Evolutionary chronology of the 5 organismic kingdoms

Communication processes we find within organisms (intraorganismic). Signals from the Mitwelt (biotic) or impressions from the Umwelt (abiotic) (Witzany 2006b) are received by sensory organs and lead to sensory computing centers in the organism where appropriate behavior is generated after internal 
interpretation of the meaning of signs which depends on the context wherein the signals are used. These communication processes function in a parallel way, intercellular (between cells) and intracellular (within cells: genomic content). Thure von Uexküll termed intraorganismic sign-mediated interactions endosemiotics (Noeth 2000). We also find communication processes between the same or related species of organisms which share a species-specific repertoire of rules and signs (interorganismic). Interestingly, we also find communication processes between non-related species (metaorganismic), and symbiotic interactions would not be possible without them. We may therefore imagine that only $20 \%$ of the cells we humans meet on our body are original human cells, and $80 \%$ are from symbiotic settlers (Blech 2000).

Following Thomas A. Sebeok, who established zoosemiotics successfully (i.e. biosemiotic investigations on animals) first steps in phytosemiotics (Krampen 1981) and 'Biokommunikation' (Tembrock 1975), I will try to complete the biosemiotic view on living nature by providing summaries of semiotic processes in bacteria, fungi and plants based on recent empirical data, as suggested in my first draft on a 'Theory of communicative nature' in the early 1990s (Witzany 1993).

\section{Rule-governed sign-mediated interactions of bacteria}

One of the most fascinating organisms are Bacteria. These unicellular organisms exist nearly 4 billion years. Bacteria (prokaryotes) communicate and therefore are able to organize and coordinate their behavior like a multicellular organism. Communication processes are rule-governed sign-mediated interactions. Signs are in most cases chemical molecules (in some cases also tactile interactions) which serve as signals both within and between prokaryotic organisms. Bacteria are symbiotic organisms in the whole range from mutualism to parasitism. They may be beneficial for their (eukaryotic) hosts without them host survival wouldn't function. Others are neutral, i.e., do not harm the host and many of them also cause diseases with sometimes epidemic character and often lethal consequences. Bacteria are important hosts for multi-viral colonization and virally determined order of nucleic acid sequences.

\subsection{Communicative competences of bacteria}

Although bacteria are relatively simple organisms they represent one of the main success stories of evolution. They started at the early beginning of life similarly to archaea which represent a different organismic kingdom (Woese et al. 1990). Bacteria are found in all ecological niches, share a common flux of their gene-pool with a high rate of gene order recombination for adaptational purposes of great diversity ( $\mathrm{Pal}$ et al. 2005). More than in any other organismic kingdom it is common use to speak about the languages of bacteria (Bassler 1999, 2002, Schauder and Bassler 2001, Ben Jacob et al. 2004).

Quorum sensing is the term of description for sign-mediated interactions in which chemical molecules are produced and secreted by bacteria (Crespi 2001, Manefield and Turner 2002, Greenberg 2003). They are recognized of the bacterial community dependent on a critical concentration and in a special ratio to the population density (Daniels et al. 2004).

These molecules trigger the expression of a great variety of gene transcriptions. Many bacteria use multiple quorum sensing codes. Each may be modulated by posttranscriptional or other regulatory engineering (Loh et al. 2002).

There are also communication processes between different species of bacteria and between bacteria and non bacterial life such as eukaryotic hosts (Konaklieva and Plotkin 2006). Beneath the semiochemicals $(G r$.: Semeion $=$ sign) necessary for developmental processes of bacterial communities such as division, sporulation, and synthesis of secondary metabolites there are physical contact-mediated behavioural patterns being important in biofilm organization (Davis et al. 1998, Fuqua and Greenberg 2002, Voloshin and Kaprelyants 2004, Parsek and Greenberg 2005). Also abiotic influences serve as signs which indicate specific nutrients or other environmental circumstances like hydrodynamic changes.

Because communities of bacteria species which are able to coordinate their behavior have advantages against single bacteria organisms it is much more common, that the evolutionary drive went into rising communicative complexity (Ben Jacob 2003). We should not forget that in comparison to the first 2 billion years of life on earth with closed prokaryotic symbiology the rise and growth of the eukaryotic 
superkingdom (protoctists, animals, fungi, plants) was a crucial advantage for bacterial lifestyle to colonize vertical hosts with their great spatial and motility resources.

We can differentiate three classes of signaling molecules for different purposes, i.e. signaling within the organism to coordinate gene expressions to generate adequate response behavior, signaling between same or related and different species. With a limited number of molecules and a limited number of combinatorial rules they generate quite different sign mediated interactions for different purposes.

As in every sign-mediated interaction sign-users share a common set of syntactic rules, i.e. how signs may be combined; of pragmatic rules which determine a great variety of interactional contexts, e.g. development, growth, mating, virulence, attack and defense. The situational context of these complex interactional processes determines the meaning of signs, i.e. semantics of signals. Independent of organismic complexity the complementarities of these three levels of semiotic rules we can identify in every sign-mediated interaction within and between organisms in principle (Witzany 2005a, 2006a).

This leads to the generation of intra- and intercellular processes which enable bacterial communities to generate memory which may be inheritable but can alter epigenetically, i.e. different reading/meaning patterns of the same genetic dataset with differences on the phenotypic level without altering the genetic dataset.

\subsection{Interpretation and coordination}

Bacteria have profound effects on human health, agriculture, industry and other ecospheres. Therefore they are target to multiply drugs which fight them (Camara et al. 2002). They develop drug resistance by coordination of special defense behavior called biofilm organization. Biofilm organization is a special kind of coordination with high density of physical contact and contact specific signaling. If bacteria realize a critical mass via quorum sensing they organize a high density of communal body by moving their flagellas which may resist even strong antibiotics (Wadhams and Armitage 2004). Biofilms are constructed on both abiotic surfaces as well as biotic ones, e.g. on stones in rivers and other aqueous surfaces or e.g., in the respiratory track of animals. Nutrient availability regulates also the structure of biofilm organization (Stanley and Lazazzera 2004) as hydrodynamic forces (Wuertz et al. 2004). Interestingly it has been found that biofilm organization is linked with coordinated DNA release which is integrated in the biofilm (Spoering and Gilmore 2006).

\subsection{Semio-chemical vocabulary of bacterial communication}

The semiochemical vocabulary used by bacteria is of great variety, ${ }^{1}$ especially because some signaling molecules are multiply re-usable components (Henke and Bassler 2004). Today three kinds of communicative goals are distinguished: $(A)$ reciprocal communication; active sign-mediated interactions which is beneficial for both interacting parts; (B) messages which are produced as response on a triggering event which may be an indicator for a receiver which was not specially targeted by the producer. A coincidental event which is neutral - except of the energy costs of production - to the producer but beneficial for the receiver; (C) signaling to manipulate the receiver, i.e. to cause a response behavior which is one-sided beneficial to the producer and harms the receiver (Visick and Fuqua 2005) often in that they behave against their normal goals (Keller and Surette 2006).

\footnotetext{
${ }^{1}$ Acyl homoserine lactones (AHLs) and linear oligopeptides are used as signs in diverse processes. Cyclized oligopeptides function as virulence genes. g-Butryolactones (GBLs) are used as antibiotics and in sporulation processes. Furanosyl diester (Al-2) is used in diverse processes (Sun et al. 2004) and in luminescence. cis-11-Methyl-2-dodecenoic acid (DSF) serves in virulence and pigmentation. 4-Hydroxy-2-alkyl quinolines (PQS, HAQs) are important in the whole regulation processes and for virulence as do palmic acid methyl esters (PAME). Putrescine is important in swarming motility like biofilm organisation. A-signal is used in early developmental processes and aggregation. C-signal is a cell sur-face-associated protein and serves to coordinate motility and the de-velopmental process of fruiting body building. Cyclic dipeptide is a secondary metabolite (Visick and Fuqua 2005).

Gram-negative bacteria use homoserine lactones (LuxR/LuxI) as signs in communication processes (Lenz et al. 2004), whereas gram-positive bacteria use oligopeptides in quorum sensing communication. As in all organisms non-coding RNAs are important in higher order regulatory path-ways. Small RNAs and microRNAs are used by bacteria to regulate special genetic expression patterns which play an important role as appropriate response behaviour to stress or nutrient availability (Teplitski et al. 2000), e.g. in controlling the quorum sensing pathways (Bauer and Robinson 2002).
} 
The three classes of intra-, inter- and metaorganismic communication enable bacteria to generate and coordinate different behavioral patterns: Self and non-self identification, i.e. "recognition" and identification of other colonies and measurement of their size, pheromone based courtship for mating, alteration of colony structure in formatting of fruiting bodies, initiation of developmental and growth processes e.g. sporulation.

In receiving signals from same or related species or non-bacterial organisms the signaling molecules bind to specialized sensor proteins which function as receptors. They transmit the message to an intracellular regulator (Fuqua et al. 1996, Visick and Fuqua 2005), i.e., the signal molecule transits the cell membrane through diffusion or by specific transport pathways. Inside the cell the signaling molecule in most cases binds to a cytoplasmic target protein. It may happen that a diffusible molecule is chemically engineered to an active signal after entering the target cell (Visick and Fuqua 2005) Organization of cellular production of response molecules leads to signal-dependent transcription control of DNA.

Bacteria have to distinguish between species-specific signaling, and signaling which is able to modulate behaviors interspecifically (Bassler 1999). With these communicative competences they are able to coordinate species-specific behavioral patterns as well as to coordinate behaviors between diverse species.

\subsection{Metaorganismic (trans-specific) communication of bacteria}

Starting with beneficial symbioses between bacteria and plants we refer to the complex communication networks between soil bacteria, mychorrizal fungi and plant roots. Mychorrizal fungi molecules secretion in the surrounding environment serve as nutrients for soil bacteria and trigger their activation to degrade special nutrients which are then available for mychorrizal fungi. Their hyphal growth serves as developmental and growth area of plant roots, themselves being depend on nutrients which are prepared by the mychorrizal fungi. Plant roots can also mimic bacterial signaling molecules either to trigger bacterial production of special molecules or to disturb bacterial communication pathways (Teplitski et al. 2000, Bauer and Robinson 2002, Witzany 2006 a, Daniels et al. 2004).

Rhizobia bacteria are integrated into plant cells by phagocytosis when they interact symbiotically with the plant roots (Samaj et al. 2004). In other cases where rhizobia fail to fix nitrogen inside the root nodules because they are cheating, plants are sanctioning these rhizobia (Kiers et al. 2003) and prevent their spread in order to stabilize mutualistic symbioses with bacterial colonies (Keller and Surette 2006). Root exudates of different kinds regulate plant and microbial communities in the rhizosphere. This is necessary to stabilize equilibrium and inhibit the continuity of attacks by pathogenic bacteria in the soil (Walker at al. 2003, Bais et al. 2003). The full range of trans-specific communication processes between bacteria and plant roots are important for developmental and growth processes in the whole plant kingdom (Manefield and Turner 2002, Sharma et al. 2003).

Chemical Molecules which serve as signs in intercellular communication processes of bacteria are similar to pheromones in social insects and animals. This may be an indicator of evolutionary lineages which evolved in the bacterial "chatter" (Velicer 2003).

Marine eukaryotes are able to mimic bacterial quorum sensing to inhibit bacterial successful communication (Rice et al. 1999). Interbacterial communication use hormone-like signaling to sense specific host locations such as intestinal habitat. In this specialized ecosphere a bacteria-host communication occurs which means the host cells and bacterial cells share a common meaning function for the same signaling molecules (Sperandio et al. 2003).

Living as endosymbionts as potential candidates for symbiogenesis (Margulis 1996, 1999, 2004, Margulis and Sagan 2002) as documented in the origin of eukaryotic endosomes like mitochondria indicates the important roles of bacteria for the whole history of evolution (Witzany 2005 a). The interactions may be pericellular colonization events but also an intracellular lifestyle. These different symbiotic interactions range from acquisition of novel genetic material to reduction in size and content connected with gene loss (Batut et al. 2004). Successful living processes of higher eukaryotes would not be able without beneficial symbiosis with bacteria. As mentioned in the Introduction the cell mass of an 
adult human resembles $20 \%$ of human origin and up to $80 \%$ of exogenic settlers (Blech 2000) most of them bacteria.

\subsection{Interorganismic communication of bacteria}

For a long time it was assumed that bacteria live predominantly as monads. Meanwhile it has been recognized that this is the very rare exception (Federle and Bassler 2003, Dunn and Handelsman 2002). Bacterial colonies live in nearly all cases not alone but in coexistence with other bacterial species selfcoordinated by a diversity of sign-mediated interactions (McNab and Lamont 2003, Ben Jacob and Levine 2006). Bacteria use intraspecific and interspecific signaling in all ecological in-vivo situations (Keller and Surette 2006). This implies also a broad variety of conflicts within and between species (Velicer et al. 2000). The mutual, neutral and manipulative aims of communication processes are special kinds of response behavior to certain degrees of beneficial up to conflictual relationships (Keller and Surette 2006).

Dependent on the availability of nutrients some bacteria suppress normal cell development which leads to the development of a different cell type which is better suited for adequate response behavior for this situational context. It means that different environmental conditions can lead to different gene expressions within the same genomic dataset. If the same colony is exposed several times to these changing contexts it has been shown that they react more immediately. This indicates that bacterial communities are able to develop collective memory and learn from the experience (Ben Jacob et al. 2004, McNab and Lamont 2003). These functions are similar to neuronal networks in higher eukaryotes. In the case of changing environmental conditions the suppression of cell division may lead to cell elongation which enables cell colony to change modus of motility. This is an important feature of socio-bacterial behavior, e.g., swarming coordination and organization for surface colonization (Shapiro 1998, 2007).

Some authors documented altruistic strategies in mixed colony formations which seem to be an advantage to the mixing among microcolonies. Altruistic behavioral strategies enable to strengthen selfidentity and a sustainable equilibrium in multilevel colonized ecological niches (Velicer and Yu 2003, Kreft 2004).

Interestingly bacteria use a common contextual interpretation of incoming signals by each member of the colony. The response behavior is appropriate to the majority vote (Ben Jacob et al. 2004) of the context dependent decision.

The identification of non-self species is a competence which is possible through species-specific and group-specific quorum sensing and is coherent with the assumption that smaller groups of the same bacterial species are able to built types of quorum sensing-"dialects". These are important in high density of coexistent bacterial life habitats to prevent confusion and enable more complex coordination (Taga and Bassler 2003). Interestingly the prokaryotic cell-cell communication has structural analogues to crosskingdom signaling between bacteria and fungi (Wang et al. 2004).

Bacteria decide in special cases to form fruiting bodies of different types and shape for sporulation. This enables bacterial communities to a more efficient dissemination of the spores. The fruiting body building is governed by pragmatic rules with different roles to different sub-groups of bacterial communities for coordination (Kaiser and Welch 2004). Some has to serve for motility to density, followed by direction decision and decision of cell types, cell growth and developmental stages in all different steps until fruiting body is ready for sporulation event.

Without communicative hierarchical organization this would not be possible. If communication is disturbed body building is not insured, so bacterial communities have developed special strategies to single out so called cheaters (Ben Jacob et al. 2004), which doesn't follow the rules to coordinate this special behavior.

One of the most interesting and best investigated phenomena of bacterial communication is the symbiology of multiple colonies coexistent in the human oral cavity (Kohlenbrander et al. 2002, Kohlenbrander et al. 2005, Rickard et al. 2006). Bacteria on human teeth and oral mucosa establish a homeostasis of pathogenic and mutualistic bacteria by a complex system of sign-mediated interactions 
both species-specific and trans-specific. The dental plaque in the oral cavity of humans is a unique habitat which isn't found in any other species. The homeostasis is not static but the result of a dynamic relationship between different species-colonies dependent on intervals of daily hygiene. The interacting species are approximately 500 different species (Moore and Moore 1994, Kroes et al. 1999, Paster et al. 2001). Each member of these communities must be able for self and non-self distinction, and to distinguish between species-specific signaling and trans-specific signaling or even "noise" (no biotic content). As community they must be able to measure their own colony size and the size of the other colonies and molecules which have the same chemical structure but are not part of a biotic message (Kohlenbrander et al. 2002, Kohlenbrander et al. 2005).

Special communication patterns with detailed hierarchical steps of signal production and transmission include (i) metabolite exchange, (ii) cell-cell recognition, (iii) genetic exchange, (iv) host signal recognition and signal recognition of same or related species. Because of the high number of competing and cooperating species there is a special short- and long time community architecture established. If the communication on the intra-, inter- and metaorganismic level is successful, i.e. the signal transmission and reception enables colonies to live in a dynamic homeostasis, then the human oral cavity will miss cavity diseases.

\subsection{Intraorganismic communication of bacteria}

Interestingly prokaryotic gene order is not as conserved as the protein sequences. Only some higher order regulations (operons) which code for physically interacting proteins are found in almost all bacterial (and archaeal) genomes. In difference to eukaryotic organisms (and few archaea) where the protein vocabulary underlies higher order regulatory functions encoded in the non-coding DNA, bacteria lack such gene order conservation.

This indicates high dynamics of new gene orders as documented in the horizontal gene transfer events with its intensive intragenomic recombination (Imaizumi-Anraku et al. 2005, Xie et al. 2004). This exchange of whole genes or gene-blocks enables bacterial lifestyles to combine several bacterial competences, i.e. phenotypes. The transformation process includes the release of naked DNA, followed by the uptake and recombination, i.e. the integration, with 17 steps identified until now, excellently demonstrated by Thomas and Nielsen (2005). So we can recognize the outcomes of a diversity of mobile DNA-contents (Bordenstein and Reznikoff 2005), not a mass of individualized genetic texts, but a bacterial gene pool as text repertoire which is available for each individual bacteria and the resource for bacterial genome innovation and evolution (Gogarten and Townsend 2005). Horizontal gene transfer is a main resource for integrating newly evolved genes into existing genomes and does not need slow steps of chance mutations to alter the genomes but accelerated genome innovations in both bacteria and archaea (Jain et al. 1999, Jain et al. 2003, Brown 2003). Important in this context of genomic innovation is not alone the sequence acquisition but the contextualization, it means also their loss (Berg and Kurland 2002). As it seems today the phylogeny of microbial species is not a tree of life, but an evolutionary network or a ring of life, mediated by genetic exchange, i.e. acquisition and loss of genetic data-sets (Rivera and Lake 2004, Kunin et al. 2005).

\subsubsection{Intracellular communication}

Signal-dependent transcription regulation of the DNA serves for a great variety of response behavior. One of the most interesting phenomenons is the fact that in the early 2 Billion years of life on planet earth the immense density of bacterial life is not an event of the mass of individual organisms but their commonly shared gene-pool which was in constant flux as we know today through investigations on horizontal gene transfer. It means that the evolution of bacteria was not a randomly event of chance mutations and their selection but transfer of whole genes and gene-blocks representing real phenotypes which were transferred. This leads to different combinatorial patterns of genetic encoded phenotypes and the raise of bacterial diversity. It also enable bacterial pathogens to optimize there disease causing coordination and is therefore target to special kind of drug developments for medical purposes (Tettelin et 
al. 2005). New empirical data seems to suggest that the phenomenon of horizontal gene transfer is driven by viral competences inherent in bacterial organisms (Villarreal 2005, Witzany 2006c).

For a long time it has been proposed that tubulin plays an important role in cytoskeletal functions of eukaryotes, whereas prokaryotes lack this system. Recent research has shown that tubulin is a very ancient system for genetic dataset segregation also in bacteria which plays important roles in filament formation, movement and orientation (Graumann 2004, Graumann and Defeu-Soufo 2004, Defeu-Soufo and Graumann 2004).

\subsection{Perspectives}

The communicative competences of bacteria enable them to develop, organize and coordinate rich social life with a great variety of behavioral patterns, and this represents one of the most successful life histories of all organismic kingdoms.

After nearly four billion years they still survive, being part of the most dramatic changes in evolutionary history such as DNA invention, invention of nearly all protein types, eukaryotic cells, vertical colonization of all eukaryotes, and high adaptability through horizontal gene transfer and multi-species colonization of all ecological niches.

Horizontal gene transfer seems to be one of the main forces in bacterial evolution because it derives from a common shared and transferable gene pool where new genetic inventions are sufficiently broad and diverse to be integrated and recombined. Bacteria are the main sources for symbiotic relationships. Without them eukaryotes would not have evolved and would not be able to survive. If we agree biology to be a history of symbiology then bacteria are the driving force for this.

Recent findings from phylogenetic analyses demonstrate that these competences of bacteria derive from the facility of viruses for natural genome-editing with an astonishing variety of genomic creativity (Ryan 2006). Bacteria seem to be the optimal biotic matrix for virally-induced genetic inventions. The communicative competences of bacteria and the genome-editing competences of viruses are therefore not divisible (Villarreal 2005).

\section{Biocommunication of fungi}

The oldest fungal fossils date from 450 million years ago. The kingdom of fungi emerged approximately 300 million years after the appearance of the first animal species, although they are descended from a common ancestor (Lengeler et al. 2000, Lang et al. 2002, Villarreal 2005). On top of that, they share common traits with eukaryotic organisms. In contrast with animal and higher plant life, monocellular representatives are fairly common among fungi, i.e. fungi are by no means mere multicellular eukaryotes. A fact that can be easily and coherently reconstructed through the lineage of Protoctista is that coordinated behavioral patterns are found among single-celled eukaryotes which closely resemble those of single-celled fungi. There are, however, unmistakable and significant differences in protoctist structures (flagellated) and those of fungi (non-flagellated). Obviously, fungi have evolved out of the coordinating competence of protoctists, such as red and joch algae (Margulis and Schwartz 1988).

\subsection{Fungal life-styles}

In difference to most animals (except corals) fungi are sessile organisms that can live for extremely long periods or extend over large areas: one exemplar has been found which covers as much as 15 hectares with an age structure of approximately 1500 years. Endolithic fungi of the Antarctic are known to be among the most long-lived organism on this planet (Villarreal 2005).

Most fungi decompose and feed on non-living organic matter. They secrete powerful enzymes that enable the cells to digest organic matter outside of their body in the nearby environment, which in turn is broken down to smaller molecules that can be absorbed and reincorporated in dissolved form. To deter 
potential predators, a number of complex and highly efficient deterring substances are produced by fungi (Margulis and Schwartz 1988).

For 1000s of years, fungal competences are actively utilized by humans in beer, wine, and bread production. Since fungi are very simple organisms, sequencing and technical manipulation are relatively easy, making them ideal organisms for laboratory experiments such as Neurospora grassa (FGSC 2005, Dunlap et al. 2004) or yeasts. For example, recent research on yeast genomes has demonstrated important features of higher order regulatory functions hidden in their DNA. Studies have showed that DNA encodes its own packaging, i.e., DNA sequences code how to package their own genome in the nucleosomes (Ercan and Lieb 2006).

Although fungal infections cause a wide range of diseases, they serve also as important resource for drug production. Their application in the medical field as producers of various antibiotics is comprehensive and well appreciated (Arora 2003).

\subsection{Semiochemical vocabulary}

Since coordination and organization processes occur in all organismic kingdoms, fungi are no exception: there are such processes during the formation of mycelia and fruiting bodies (intraorganismic), between species of same kind (interorganismic) and between fungi and nonfungal organisms (metaorganismic) (Witzany 2007 a). These processes occur as rule-governed sign-mediated interactions. The signaling processes are nothing else but distinct biosemiotic communication processes (Witzany 2006 b). The used semiochemicals (Sullivan and Berisford 2004) are of biotic origin and they trigger the fungal organism to react in a specific manner, in difference while to even the same chemical indicators molecules are not being a part of biotic messages doesn't trigger to react the fungal organism. It means fungal organisms are competent to identify the difference of the same molecules being part of biotic messages or lack of these features.

So far five different primary signaling molecules are known that serve to coordinate very different behavioral patterns such as filamentation, mating, growth, pathogenicity (Adachi and Hamer 1998, Wang and Heitman 1999, Hemenway and Heitman 1999, Alspaugh et al. 2000, Borges-Walmsley and Walmsley 2000). Behavioral coordination and the production of such substances can only be achieved through interpretation processes: self or non-self, abiotic indicator, biotic message from similar, related, or nonrelated species, or even "noise", i.e., similar molecules without interpretational content. Furthermore, there are numerous, lesser-investigated subunits that attain an accompanying role as they are weaker in effect (Lengeler et al 2000). Globally, these semiochemicals serve to coordinate similar goals in different fungal species, yet species variation among them cannot be ignored. ${ }^{2}$

Up to now 400 different secondary metabolites have been documented. These are known to contain mycotoxins and are used both for defensive and aggressive behavioral patterns.

\subsection{Internal interpretation of external abiotic influences}

Fungi react sensitively to varying nutrient availability and nutrient fluxes, responding by initial intraorganismic communication. That is, in case of carbon or nitrogen insufficiencies, the internal communication of the organism responds adequately and is phenotypically expressed by a change in hyphael growth. Up to now, two specific signaling pathways have been found that coordinate such behavior. These diverging patterns have also been documented among other fungi, including those that are pathogenic to plant and animal life (Lengeler et al. 2000).

\footnotetext{
${ }^{2}$ These patterns regard: (Fernandes et al. 2005)

a) cell integrity, cell wall construction, pheromene/mating and osmo-regulation by mitogen activated protein kinase signaling (MAPK).

b) fungal development and virulence by the cyclic adenosine monophosphate cAMP/PKA system

c) cross-talking between signaling cascades by the RAS protein

d) cell survival under oxidative stress, high temperature, membrane/cell wall perturbation by calcium-calmodulin-calcineurin

e) control of cell growth and proliferation by rapamycin
} 
As animals and plants, seasonality as a part of the circadian system is also found in fungi (Dunlap et al. 2004). In particular, it regards light regulated physiologic processes that coordinate the internal fungal clock (Bell-Pederson et al. 1996).

Almost all fungi digest food outside their bodies: the excretion of extracellular digestive enzymes fragments larger biomolecules and makes them soluble, which are then readily accessible for the fungal organism. This is particularly important for the digestion of cellulose (through enzymatic activity of exocellulase and endocellulase, lignin, i.e., lignin peroxidase and manganese peroxidase). Enzymatic breakdown of organic matter yields simple sugars, amino acids, fatty acids and other smaller molecular components (Margulis and Schwartz 1988).

\subsection{Metaorganismic (trans-specific) communication}

One of the most striking trans-specific (metaorganismic) communication processes between fungi and non-fungal species can be found in lichens. Fairly early associates of the fungal kingdom are those organisms that interact symbiotically with fungi, as is the case with lichens. All higher fungal life-forms originated from these symbiotic ways of life, which later became independent by detaching themselves from this close and vital dependence. Lichens are complementary symbiotic partnerships between photobionts (algae or bacteria with fungi), (Sanders 2006) i.e., they are viable only together (Sanders 2001). As pioneering organisms, they may settle on blank rock. Being essential bioeroders, they extract nutrients from mineral matter, thereby initiating the process of soil formation and paving the way for successive organisms that include even root-forming species.

Lichens are polyphyletic. They have been derived many times independently from different kinds of ascomycetes, so undoubtedly, their nature of symbiosis varies (Raven 2002). In lichens the algae provides the fungi with photosynthate, while the fungi caters the algae with nutrients. Lichens constitute one of the oldest known fungal members and are capable to resist quite averse environmental conditions. The symbiosis between fungi and algae or fungi and bacteria result in a mutual supply of nutrients and their associated competences. Through quorum sensing, the fungi benefit from the bacterial association (Hogan 2006). In turn, the bacteria utilize dissolved fungal metabolites to satisfy their nutritional requirements. A similar co-dependence is observed with algae as symbiosis partners.

Fungi are known to utilize a broad variety of different symbiotic interactions with animals, plants and eukaryotic unicellular organisms for both mutual benefit as well as parasitic and even lethal associations. They also settle on specific types of tissue. Fungal diseases are known to affect both plant and animal life where they can induce devastating effects in agriculture. A typical example of mutually beneficial symbiosis can be found between the bark beetles and quite a few different fungi (Sullivan and Berisford 2004). The fungal spores benefit from the locomotion provided by the beetles in several aspects: access to new hosts, while the beetle benefits by the availability of fungal nutrients and pheromones. Some fungi provide nitrogen, amino acids and sterols, which are crucial for the development of beetle larvae, however, this gives effect only once the adult beetle has colonized a host. Interestingly many bark beetles even evolved transportation pockets for fungal hyphae, which points at the common evolutionary history (Kopper et al. 2004).

Another metaorganismic symbiotic signaling happens between fungi and ants which derives from a coevolutionary relationship which lasted for over millions of years (Poulsen and Boomsma 2005). Interestingly, some lignin-degrading fungi also produce semiochemicals which have effects on the feeding and foreaging behavior of a Formosan subterranean termite (Cornelius et al. 2004).

Many of the known indicators stress the fact that both the fungal as well as the animal kingdoms share common ancestors, such as protoctists with a true nucleus like choanoflagellates (Villarreal 2005). With reference to this, fungi and animals are more related to each other than to the plant kingdom. This is further strengthened by the sign-mediated processes, which regulate cellular functions. Yet, a different indicator of their common ancestor is found in a particular signaling pathway, termed mitogen activated 
protein kinase cascade (MAPK). It plays a crucial role in cell wall stabilization of fungi and pheromone/mating interaction among mammal cells.

Then, there are fungi, which parasitize plants. For example, they colonize host tissues with an intercellular mycelium that forms (haustoria, i.e.,) fungal mats within plant cells (Jakupovic et al. 2006) that penetrate the cell to utilize the nutrients of the plant. Investigations of hazardous fungal infections on plants revealed the crucial role of enzymes such as cutinase, pisatin, demethylase and HC-toxins (NIAID 1993).

Today, several hundred species of fungi colonize more than 100,000 different plant species. This type of cohabitation requires symbiotic signaling (Lammers 2004), e.g. the starting of filamentous growth of fungi through plant hormones (Prusty et al. 2004). Roots of plants provide better conditions for mycorrhizal fungi, which in turn supply plants with better nutrients (Brundrett 2002). For the fungus, such a relationship is either balanced or predatory. Endophytic fungi, however, live in plants without triggering symptoms of disease (Walker et al. 2003). Today, scientists consider the origin of plant cell to be the result of terrestric activity of mycorrhiza; i.e., settlement on land is a coevolutive event that is comparable in the mode of complementarities to that between flowering plants and insects (Villarreal 2005). Thereby fungi excrete digestive enzymes into the surrounding soils, convert nutrients into aqueous solutions that in turn can be readily absorbed by the plant (Walker et al. 2003). Therefore, staggering majorities of $80 \%$ of all terrestrial plants, especially trees, rely on the activity of mycorrhiza (Schwarze et al. 2004).

Fungi affecting animals are usually dependent on the host's body temperature; i.e., only if the body temperature is sufficiently high, host colonization by the fungi is possible. Especially Aspergillus Fumigatus colonizes animal hosts if they are under thermal stress (Bhabhra et al. 2006). Although fungal disease is common in birds, the relative resistance of endothermic vertebrates to fungal diseases may be a result of immune responses connected with higher body temperature (Casadevall 2006).

\subsection{Interorganismic (species-specific) communication}

Since there are both single and multicellular species, determination of communication processes between same species and related fungal species cannot be distinguished unambiguously from intercellular communication (intraorganismic). Thereby communication processes of monocellular yeast (Banuett 1998), which resembles that of amoeba like Dictyostelium, must be considered as interorganismic communication, whereas cell-to-cell communication between multicellular fungal species is truly intercellular. To verify whether cell-to-cell communication is inter- or intraorganismic, we have to consider intercellular processes on a case-by-case basis.

Herein lies another fundamental characteristic of biota: it regards the identification competence for the determination of "self" and "non-self". This competence could be successfully proven in Neurospora crassa (Glass et al. 2000, Glass and Saupe 2002, Glass and Kaneko 2003). It is obvious that this competence to distinguish between oneself and the others is vital for fungi; that is, the encounter of mycelia among same species results in the merger of their fungal hyphae. However, such dikaryotic mycelia can also result from the merger of different fungal species. While peripheral hyphae tend to avoid merging with hyphae of other species, the opposite is the case with those at the center of the mycelium (Glass et al. 2000, Glass and Saupe 2002, Glass and Kaneko 2003).

If one assigns mycelia the role of a wrapper within which the fungi, so to speak, is enveloped into a fluid-like continuum, nuclei of compatible but different species are then "flowing" through the same mycelium. The overall result is an organism, which houses nuclei of different genetic origin in its cytoplasm (Wu and Glass 2001). However, if specific genetic sequences are incompatible, then repulsion sets in forcing the approaching hyphae to an immune-like response.

Resource competition in fungi occurs directly, indirectly and via mechanic interaction. Indirect competition involves absorption of all available resources within the reach of the mycelium, thereby famishing potential competitors by maintaining a nutritional deficiency gradient. Direct interaction, on the other hand, involves secondary metabolites, which suppress growth or even induce death of the competing fungi. The antibiotics employed in such cases can be either volatile or non-volatile. Mechanical 
interaction simply requires overgrowth of one fungal species by the other, in which the overgrowing species exerts its lytic action on the other. In some cases lysis is induced via antibiotical agents (Dix and Webster 1995, Griffin 1994).

As bacteria are also single-celled, fungi use quorum sensing to regulate and affect biofilm formation and pathogenesis (Reynolds and Fink 2001). This is mediated by small molecules which accumulate in the extracellular environment. If it reaches a sufficiently high concentration a response regulator is activated within the local population of cells leading to the coordination of a special gene expression (Hogan 2006).

In parasitic interactions between fungal organisms even cytoplasmic fusion during infection processes was found which indicated genetic transfer in the host parasite relationship. The recognition pattern in this predatory-prey relationship is mediated by trisporoids which also serve in a non-parasitic behavioral pattern, i.e., is responsible for sexual communication (Schultze et al. 2005).

\subsection{Intraorganismic communication}

The countless variety of fungal organisms represents a major challenge when establishing a homogeneous designation of the sign processes employed. Research activities so far have predominantly focused on those fungal species that posed a serious threat to agriculture, are pathogenic to humans or possessed antibacterial properties. Species of this kind are relatively well investigated, whereas species with obviously insignificant properties are hardly known.

\subsubsection{Intercellular communication}

Higher Fungi are modular hyphal organisms in that they reproduce by clonation or also parasexually: They establish interlocked networks. Like red algae they "merge" their cytoplasms to form multi-nucleated cells. A spore germinates under appropriate environmental conditions and is followed by the formation of filaments called hyphae. The latter is characterized by nuclear division and spore formation, which develops into monokaryotic filaments (tip growing). The embryological stage, a characteristic of higher plants and animals, is completely absent in fungi (Margulis and Schwartz 1988). Hyphae formation is also found among certain bacteria, like Streptomyces and Actinomyces. Hyphae tightly packed together into a mat are called a mycelium. Each filament of hyphae has tubular side walls made mostly of chitin, a feature that is common also in Arthropoda. The cell walls that seem to separate adjacent cells in a filament are called septa; however, their porous nature does not really assign them separating properties. The merger of filamental tips of the same or different species triggers a self / non-self identification process. This process is sign-mediated and results either in repulsion or attraction. If the latter occurs, merger to a dikaryotic mycelium takes place and initiates the formation of a fruiting body. Hyphal growth is a totally different pattern of conduct than normal cell growth: such cells change shape, become long, and reorientate themselves into specific directions to come into physical contact or even "merge" with each other only to colonize a potential growth resource - usually dead organic matter. Fungal hyphae simultaneously extend into a given direction only when nutritional resources are ideally distributed. However, this is a rare event. Usually the fungi propagate in the conditions rich with organic matter (carbon and its derivatives) just to halt growth when little or no resources are available; here the fungi coordinate their growth by employing certain properties. In order to do so, the fungi use intercellular signals that enable them to comprehend the overall state of the organism. Once the fungus encounters a resource-depleted substrate or even poisonous compounds, it responds by halting its growth cycle or by propagating in another direction (Belozerskaya 1998). ${ }^{3}$

\footnotetext{
${ }^{3}$ The protein signals involved in such processes are quite complex: the apex of hyphae houses specialized receptors that are able to respond to any environmental condition. Any carbon-enriched substrate makes these receptors active, which in turn results in the production and release of protein signals into the hyphal cytosol where the corresponding signaling cascade is triggered. In turn, the mycelium responds with the mobilization and translocation of resources into the activated area. In the absence of carbon-rich substrates, or at increasingly acidic $\mathrm{pH}$ levels, the hyphae responds by activating yet other receptors that slow down growth and eventually make the organism withdraw resources from the affected area. Since septa within the hyphae are perforated, they perform
} 


\subsubsection{Intracellular communication}

By investigating a great number of signal transduction events from the outside through the cell membrane into the cytoplasm, it was possible to decode some important intracellular communication processes. Thereby, it has been found that sign processes coordinate cell polarity, mating, pheromone control and cellular morphology. Some of these sign processes even adjust the cell cycle, perform polarized growth activity and modify the transcription profiles of fungal cells (Lengeler et al. 2000, Bardwell 2004, Fernandes et al. 2005). By examining the fungal pathogen Paracoccidioides brasilienus it has been revealed that some signaling pathways are identical to those of other species such as in Saccharomyces cerevisiae, Cryptococcus neoformans, Candida albicans and Aspergillus fumigatus (Fernandes et al. 2005).

The involved "protein cascades" that characterize production pathways of appropriate chemicals and messenger signals regard behavioral contexts, which are to some extent completely different as outlined in the chapter about semiochemical vocabulary (Fernandes et al. 2005). In addition, combinatorial communication procedures such as MAPK and CAMP pathways are also part of the behavioral contexts (Lengeler et al. 2000). This in turn serves to multiply the semantic contents of the encoded messages.

To sense extracellular stimuli and convert them into intracellular signals which regulate developmental and growth processes several signaling pathways have been found. The guanine nucleotide-binding protein (G-Protein) is essential for extracellular detection of nutrients and sexual partners (Dohlman 2002, Kays and Borkovich 2004, Hoffman 2005). The TOR protein kinases which are bind and inhibited by rapamycin function as nutrient-sensing signals and regulate cellular responses like proliferation, transcription, translation, autophagy and ribosome biogenesis (Beck and Hall 1999, Cutler et al. 2001, Crespo and Hall 2002, Rohde and Cardenas 2004).

As with any sign-mediated interaction that can be achieved with molecules, the same components are employed for different behavioral contexts and in various messages. That is, different modes of behavior can be coordinated by syntactic identical molecules. The signaling pathways use identical proteins to coordinate different response patterns. Even if they are syntactically identical they have completely different meaning. For example, activated cAMP triggers filamentous growth in Sacharomyces cerevisiae, regulates positive virulence in Cryptococcus neoformans, suppresses mating in Schizosacharomyces pombe and inhibits filamentous growth in Ustilago maydis (Lengeler et al. 2000, D'Souza and Heitman 2001) or activates protein kinase for directly or indirectly indicated developmental changes in Magnaporthe grisea during infection of rice (Mitchell and Dean 1995). Another example is the Ustilago maydis pheromene response which regulates both the cell fusion as well as the pathegenicity program for plant infection (Krüger et al. 1998, Hartmann et al. 1996, Hartmann et al. 1999).

These examples show that different behavioral contexts determine different meanings of identical signaling molecules, or in biosemiotic terms, pragmatics determines semantics of syntactic identical substances. In such cases, biosemiotically identical signs induce opposite responses in their associated life-related relationships among different organisms. It is interesting to note, how fungi are not just capable to differentiate various messages and to respond appropriately, but moreover, to differentiate molecules that are chemically identical from molecules which obviously contain no relevant meaning („noise“), i.e., they are not parts of biotic messages.

Recent genome comparison has given new insights in evolutionary aspects of fungi. The thesis that evolution happened through whole genome duplication events, followed by selective gene-loss and stabilization, is strengthened by analysis on Saccharomyces cerevisiae (Kellis et al. 2004). Interestingly, the signal-to-noise ratio in yeasts is approximately $70 \%$ protein coding regions and $15 \%$ regulatory elements in the non-protein coding regions in comparison to humans with $3 \%$ and $97 \%$, respectively (Kellis et al. 2003).

similar functions as observed with the gap junctions in higher animals, micro-plasmodesmata in cyanobacteria or plasmodesmata in higher plants (Belozerskaya 1998). 
The important role of Viruses in the evolution of fungi especially virally induced natural genome editing functions for the evolution of fungal communicative competences is not part of this contribution but outlined in great detail elsewhere (Witzany 2007b).

\subsection{Perspectives}

An overview of significant levels of fungal communication shows that identification of sign-mediated processes in signaling pathways is context-dependent - within and among fungal cells as well as between fungi and other organisms.

Such dependence is prevalent in either (beneficial or parasitic) colonization or defense responses. Depending on the utilization context, molecular components are integrated into unique signaling pathways where they gain corresponding meanings. Such meanings are subject to change, i.e. they rely on various behavioral contexts which differ in changing conditions. These contexts are concerned with cell adhesion, pheromone response, calcium/calmodulin, cell integrity, osmotic growth, and stress-response or cell growth through rapamycin. The interactional context (pragmatics) determines the semantic relation, i.e. its meaning and the function of the chemical components, and is found to be a sign-mediated communicational pattern of fungi.

Recognizing how versatile fungal communication competences really are, we can see that a primary principle is followed throughout all these signaling processes: with a core set of chemical molecules fungal organisms coordinate all their behavioral patterns (Witzany 2007 a). The interactional (pragmatic) context and the different modes for coordinating appropriate response behavior, e.g. development, growth, mating, attack, defense, virulence, etc., determine combinations of signals to generate the appropriate meaning-function, i.e. informational content of messages. In contrast with former systematisations which have been investigating combinatorial rules of meaning and functions in signaling molecules, the biosemiotic perspective differentiates all three levels of rules involved in signaling, the syntactic level (combinations), the pragmatic level (context) and the semantic level (content). These generating processes normally function in a very conservative way but under certain circumstances may fail, or selective pressure may lead to changes which can be a driving force in fungal evolution.

\section{Biocommunication of plants}

Also plants are sessile organisms that actively compete for environmental resources both above and below the ground. They assess their surroundings, estimate how much energy they need for particular goals, and then realize the optimum variant. They take measures to control certain environmental resources. They can distinguish between self and non-self. This capability allows them to protect their territory. They process and evaluate information and then modify their behavior accordingly.

\subsection{Introduction}

We will notice that the highly diverse communicative competences of plants are possible due to parallel communication processes in the plant body (intraorganismic), between the same and different species (interorganismic), and between plants and non-plant organisms (metaorganismic). Successful communication processes allow the plants to prosper; unsuccessful ones have negative, potentially lethal repercussions. Intraorganismic communication involves sign-mediated interactions in cells (intracellular) and between cells (intercellular). Intercellular communication processes are crucial in coordinating growth and development, shape and dynamics. Such communication must function on both the local level as well as between widely separated plant parts. This allows plants to react in a differentiated manner to its current developmental status and physiological influences.

As we will see, communicative competence refers to chemical and physical communication processes. Chemical communication is either vesicular trafficking or cell-cell communication via the specifity of plant tissue connections ("plasmodesmata"). Moreover, numerous signal molecules are produced in or 
controlled by the cell walls. Physical communication takes place through electrical, hydraulic and mechanical signs.

\subsection{Chemical vocabulary}

The chemical communication in and between plants is so complex that more than 20 different groups of molecules with communicatory function have currently been identified.

Up to 100, 000 different substances, known as secondary metabolites, are active in the root zones of plant organisms, for example. This diversity is necessary considering the high diversity of microbes, insects and plants in this zone (Bais et al 2003). For example, the continuous defense against pathogenic microorganisms in the root zone requires the constant production, exact dosage and secretion of phytoalexins, defense proteins, and other substances (Flores et al. 1999). Examples of the molecular vocabulary in plant communication include a broad variety. ${ }^{4}$

\footnotetext{
${ }^{4}$ Major Substances are auxin, several hormones, RNAs and multiply-reusable components:
}

a) Contextdependent Auxin (as neurotransmitter, hormone, morphogenic sign)

Plant roots and plant shoots (stems) detect environmental signals as well as development levels and communicate over longdistance pathways. The decentralized nervous system of plants is advantageous for decentral growth and development under constantly changing environmental conditions (Baluska et al. 2004b). Auxin is used in hormonal, morphogenic and transmitter signaling pathways. Because the context of use can be very complex and highly diverse, identifying the momentary usage is extremely difficult (Baluska et al. 2005a). For synaptic neuronal-like cell-cell communication, plants use neurotransmitter-like auxin (Schlicht et al. 2006) and presumably also neurotransmitters such as glutamate, glycine, histamine, acetylcholine, dopamine - all of which they also produce (Baluska et al. 2004a). Auxin is detected as an extracellular signal at the plant synapse (Baluska et al. 2005a) in order to react to light and gravity. However, it also serves as an extracellular messenger substance to send electrical signals and functions as a synchronization signal for cell division (Campanoni et al. 2003). In intracellular signaling, auxin serves in organogenesis, cell development and differentiation. In the organogenesis of roots, for example, auxin enables cells to determine their position and their identity (Casson and Lindsey 2003). The cell wall and the organelles it contains help regulate the signal molecules. Auxin is - as the name suggests - a growth hormone. Intracellularly, it mediates in cell division and cell elongation. At the intercellular, whole plant level, it supports cell division in the cambium, and at the tissue level it promotes the maturation of vascular tissue during embryonic development, organ growth as well as tropic responses and apical dominance (Friml and Wisniewska 2005).

b) Hormones

Alongside the classical phytohormones auxin, cytokinin, gibberellin, ethylene and abscisic acid, the plant peptide hormone systemin has noticed to be important; plants use this to systematically react to local injuries (Xia 2005). For example, the abiotic stress hormone absisic acid imparts disease resistance by acting on several levels involved in biotic stress signalling (Mauch-Mani and Mauch 2005). Peptide signal-mediated responses are merely one part of a biological process that is controlled by a combination of several hormones. In activating an effective defense response, a combination of systemin, jasmonate and ethylene serves as signal molecules (Xia 2005).

The production (biosynthesis) of brassinolide hormones is important for cellular processes and development steps. They are therefore termed metahormones (Amzallag 2002). Arabidopsis plants that lack this hormone remain small and are male-sterile. Many plant hormones apparently play a key role as signals in cell functions and developments that enormously impact the activities of insects. Plant hormones control not only plant growth and development but also serve in communication within the same species, with related or unrelated plant species, and with insects, i.e. they serve in classical metaorganismic communication. Plants and insects produce their hormones differently but apply them for similar purposes, namely to coordinate overall development, points to their use in their unicellular ancestors (Thummel and Chory 2002).

c) RNAs

Plants can react to the full range of outside influences only through behaviors that are expressed in growth and development; correct timing, which can be very precise, is crucial (Flemming 2005). Beyond phytohormones, the chemical messenger substances include peptides such as phytosulphokine growth factors and RNAs. Micro-RNAs play an important role in intracellular communication during plant development, either in cleavage during translation/transcription or in preventing translation. Micro-RNAs are apparently necessary for meristem function, organ polarity, vascular development, floral patterning and hormone response. Many of them are developmentally or environmentally regulated (Kidner and Martienssen 2005). Small interfering RNA probably serves as a signal during early development. In later developmental phases, the RNAi-dependent epigenetic processes are reminded of this early development phase, for example the heterochromatin configuration. At any rate, these RNAs play important roles in chromatin regulation and therefore in epigenetic silencing (Kidner and Martienssen 2005).

d) Multiply re-usable components

Small molecules and proteins that normally support important functions in plant immunity, such as nitric oxide and Reactive Oxygen Species (ROS), have now been identified as multiply re-usable components of other biological processes. Messenger substances and signal molecules are used as a versatile basic vocabulary in other contexts and other regulation networks - a common principle in the evolution, growth and development of organisms (Farmer and Schulze-Lefert 2005, Torres and Dangl 2005). Nitric oxide (NO) is a substance that has a regulatory function in numerous signal processes such as germination, growth, reproduction and disease resistance (Delledonne 2005). The same is true for diverse species of ROS (Apel and Hirt 2004, Carol and Dolan 2006). 


\subsection{Interpretation of mechanical influences}

Mechanical contact has an influence on the overall organism and on the cell level, both in plants and in other eukaryotes. Contact can cause plants (A) to react aggressively, for example toward the animals that want to eat them, (B) to discard their pollen, and (C) can cause the plant stem to grow into the sunlight (Braam 2005). The entire configuration of a plant (morphogenesis) is partially determined by mechanical inputs, for example wind and gravity (Morita and Tasaka 2004). Responses to contact involve signal molecules and hormones along with intracellular calcium, reactive oxygen, octadecanoids and ethylenes. Another common feature is contact-related gene expression. Many of these genes code for calcium bonds, cell wall changes, defense, transcription factors and kinase proteins (Braam 2005).

The detection of resources and their periodic, cyclic availability plays a key role in plant memory, planning, growth and development. When, for example, young trees obtain water only once a year, they learn to adjust to this over the following years and concentrate their entire growth and development precisely in the expected period (Hellmeier et al. 1997).

Interpretation processes in the plant body are highly sensitive. In taller-growing plants, for example, the water balance places enormous demands on cell wall development and cell wall structures, which must adapt to the often extreme pressures involved in storage and pressure distribution. A sophisticated and multi-leveled feedback- and feed-forward-system guarantees a plant-compatible water balance even under extreme environmental conditions (Zimmermann et al. 2004, Buckley 2005). To date, 7 different levels of sensitivity to water shortage have been described. They are based on the different types of physiological and phenotypic responses. Plants are especially sensitive to light and have various receptors for UV, blue, green, red and far-red light (Trewavas 2005). The angle of the light, combined with sensation of the growth of adjoining plants, is decisive in enabling plants to coordinate their growth with respect to the optimal light angle and shade avoidance (Ballare 1999). The adaptive response of the plant, i.e. altered growth, depends on the seconds-, minutes- and hours-long dominating wavelength of the incoming light, and on the combination of wavelengths across the whole day. The roots receive constant signals from the aboveground parts of the plant for specific growth orientations (Baluska et al. 2006).

\subsection{Metaorganismic (trans-specific) communication}

Sign-mediated interactions with organisms belonging to other species, genera, families and organismic kingdoms are vital for plants and are coordinated and organized in parallel. They are almost always symbiotic or parasitic and range from mutually beneficial via neutral, up to damaging behaviors. The different forms of symbiotic communication require very different behaviors from the participating partners. This involves large numbers of complementary direct and indirect defense behaviors (Trewavas 2003).

\subsubsection{Coordination of defense}

A good example of parallel meta-, inter- and intraorganismic communication are coordinated defense strategies of plants. Chemical signal substances are the oldest form of signs and are used by microbes, fungi, animals and plants. They are transmitted via liquids in the environment or within the plant body; they can be distributed and perceived through the atmosphere. Leaves always emit such volatiles in small doses, but emit greater quantities when infested by parasitic insects. This allows them to attack the parasites either directly by producing substances that deter them, or indirectly by attracting other insects that are natural enemies of the parasites. These volatiles are also perceived by neighboring plants, allowing them to initiate preemptive defensive responses (Pare and Tumlinson 1999). Volatile phytochemicals serve as airborne semiochemicals. Depending on the behavioral context - destruction, injury or parasitic infestation - the emitted scents clearly differ for both the insects and neighboring plants (Pare and Tumlinson 1999). The plants coordinate complementary direct and indirect defense mechanisms in a step-wise manner and tailor them flexibly to the severity of the injury or the density of pest infestation (Kant et al. 2004, Engelberth et al. 2004). 
When plants are attacked by pests, they develop immune substances that have the same function as in animals (Nürnberger et al. 2004). Injured plants produce aromatic substances that warn other plants. They then rapidly produce enzymes that make the leaves unpalatable for herbivorous insects. Rather than being passive prisoners of their surroundings, plants are active organisms (Peak et al. 2004) that identify their pests and actively promote the enemies of these pests (Van der Putten et al. 2001).

In lima beans, for example, a total of 5 different defense strategies against mite infestation have been discovered. First, they change their scent to make them unattractive to the mites. Then the plants emit scents that are perceived by other plants, which then do precisely the same thing to warn surrounding lima beans before the mites even reach them. Some of the emitted substances had the effect of attracting other mites that ate the attacking red mites (Mithöfer et al. 2005). Similar defense processes have been described in tomato plants (Kant et al. 2004, Pearce and Ryan 2003).

Plants possess a non-self warning system to fend off dangerous parasites. So-called pattern recognition receptors detect patterns of chemical substances associated with parasite infestation (Zipfel and Felix 2005). The microbes, in turn, react to this pattern recognition (Noumra et al. 2005).

Because plants are sessile, their reaction potential is geared toward defense against mechanical damage and pest infestation. One of the many reaction types to infestation is the production of protease inhibitors I und II, which block protein degradation in the digestive tracts of insects. This defense reaction is produced both at the injured site and throughout the surrounding tissue: the local wound response triggers the production of mobile signals that prompt a systematic reaction of the overall plant (Xia 2005).

Plant roots have the capacity to produce 100,000 different compounds, largely secondary metabolites, many with cytotoxic properties, in order to prevent the spread of microbes, insects and other plants (Bais et al. 2003, Walker et al. 2003). For example, plants have developed defense strategies in which substances are emitted in the root zone such as signal mimics, signal blockers and/or signal-degrading enzymes to respond to bacterial quorum sensing (Walker et al. 2003). In the defensive position, they can disrupt the communication of parasitic microorganisms to the point that the internal coordination of the parasitic behavior collapses.

"Friendly" arthropods such as predaceous or fungivorous mites are supported by plant "domatia", similar to the situation in complex communities of grasses and fungal endophytes. These symbiospheres, however, can also be misused, for example by mites that colonize these domatia for themselves without benefiting the host cell (Romero and Benson 2005).

\subsubsection{Symbioses by communicative coordination}

A limited number of chemical messenger substances is available to maintain and simultaneously conduct the communication between (A) root cells of three different types, (B) root cells and microorganisms, (C) root cells and fungi, and (D) root cells and insects (Bais et al. 2003, Walker et al. 2003, Callaway 2002, Dessaux 2004, Dunn and Handelsman 2002, Teplitski et al. 2000). The communication process in the root zone is generally meta-, inter- and intraorganismic and requires a high communicative competence in order to be successfully interactive on all three levels and to distinguish messenger molecules from molecules not being part of messages (Federle and Bassler 2003, Hirsch et al. 2003, Sharma et al. 2003).

It has been postulated that the origin of root cells in plants, and therefore the basis for the youngest organismic kingdom on our planet, arose through the symbiogenesis of fungi and algae (Jorgensen 1993, Zyalalov 2004, Baluska et al. 2006). One hypothesis assumes that land plants are the symbiogenetic product of green algae and a tip-growing fungus-like organism that combined autotrophic and heterotrophic capabilities (Jorgensen 2004).

\subsubsection{Symbiosis of plant roots with bacteria, fungi and insects}

Plants use their plant-specific synapses (Baluska et al. 2006) to conduct neuronal-like activities and establish symbiotic relationships with bacteria (Denison and Kiers 2004). Similar mutually advantageous relationships are established with mycorrhizal fungi (Vandenkoornhuyse et al. 2002). A special type of 
plant synapse resembles the immunological synapse of animal cells and allows plants to respond to pathogen and parasite attacks as well as to establish stable symbiotic interactions with rhizobia bacteria and fungal mycorrhiza (Baluska et al. 2006, Estabroock and Yoder 1998, Yoder 1999, Keyes et al. 2000, Kahmann and Basse 2001, Imaizumi-Anraku et al. 2005). Electrical signals can reinforce chemical signals or overcome short-distance responses of fungal mycelia that can be present on root surfaces (Van West et al. 2002). Interestingly, rhizobia bacteria are taken up in plant cells via phagocytosis during symbiotic interactions with roots of leguminous plants (Samaj et al. 2004).

The symbiotic relationship between legumes and rhizobial bacteria leads to the formation of nitrogenbinding nodules in the root zone. Nod factor signaling and thigmotrophic responses of root hairs overlap here as well. This once again shows how the same pathways are used for different signal processes (Guerts et al. 2005).

Plants, insects and microbes share a particular repertoire of signals. Some are therefore also employed strategically. Thus, plants also use insect hormones (prostaglandins) for specific defense behavior. Signal theft is common. Because plants can detect their own signals, they can presumably also detect similar signals that are used in communication between insects (Schultz and Appel 2004).

\subsubsection{Viral symbiotic interactions}

In particular, the evolution of plant viruses shows that viruses complement plants both competitively and symbiotically. A healthy plant body is better for most viruses than a sick body. Plant viruses and their development provide a good explanation for the observation that new species originate through symbiogenesis (Roossinck 2005). Viruses use intergenomic gene transfer and intragenomic duplication. ${ }^{5}$

One of the interaction processes between plant viruses and their host organisms creates a defense level against foreign nucleic acids (Dunoyer and Voinnet 2005a). Plant viruses code for silencing suppressors in order to act against host RNA silencing, and some of these suppressors effect micro-RNA multiplication and hinder plant development (Wang and Metzlaff 2005). But also viroids play a symbiotic role. Despite their small size and their non-coded genome, viroids can multiply, systematically spread from cell to cell, and trigger symptoms in the host (Dunoyer and Voinnet 2005b).

\subsection{Interorganismic communication}

Research has shown that plants can distinguish between damage caused by insects and mechanical injuries. Mechanically injured plants emitted substances that were ignored by neighboring plants, whereas all reacted immediately to pest infestation.

Plants can distinguish between self and non-self. Thus, defense activities are initiated against foreign roots in order to protect the plant's own root zone against intruders. The individual sphere of a root, along with its symbiotic partners, requires certain fundamental conditions in order to survive and thrive. When these prerequisites are threatened by the roots of other plants, substances are produced and released in the root zone that hinder this advance (Bais et al. 2003, Walker at al. 2003, Dessaux 2004, Dunn and Handelsman 2002). Such defense activities are also deployed as anti-microbial substances against the microflora in the root zone.

Plant roots produce a wide range of chemical substances: (A) some enable species-specific interactions; (B) many of these substances are released tens of centimeters into the surroundings; (C) these substances have strong but not necessarily negative effects on animals, bacteria, viruses and fungi; (D) released substances have a defensive function against other plants; (E) many substances have absorptive characteristics that reduce the negative effects of substances (Bais et al. 2003).

\footnotetext{
${ }^{5}$ Many DNA viruses have encoded numerous nucleic acid metabolisms that are very similar to cell proteins. Examples include DNA polymerases, ribonucleotide reductase subunits, DNA-dependent RNA polymerase II subunits, DNA topoisomerase II, thymidylate synthase, helicases and exorbinuclease. Viruses probably invented DNA to protect their genetic material from being changed by Ribozymes (Shakelton and Holmes 2004).
} 
As reported above in lima beans and tomatoes, also corn plants use a sophisticated communication system to warn each other about pests. By emitting green leafy volatiles, the corn plants attract the natural enemies of the pests and alarm neighboring plants. The alarmed neighbor then produces a protective acid that is normally produced only in response to external injuries (Engelberth et al. 2004).

Plants use biotic signals to inform each other about the presence, absence and identity of neighboring plants, growth space, growth disturbances and competition (Callaway 2002). Plants that are removed and planted elsewhere remember the identity of their former closest neighbors for several months (Turkington et al. 1991). Recognition patterns in neuronal-like networks are one possible explanation.

\subsection{Intraorganismic communication}

As opposed to the central nervous system of animals, which controls metabolism and reactions centrally, the control in plants is decentral (Xoconostle-Cazares et al. 1999, Baluska et al. 2004 b). This enables plants to start independent growing or developmental activities in certain regions of their body, for example on how a particular branch should grow, depending on the wind, light angle and overall "architecture" of the plant (Trewavas 2005). Most of the activities that plants make with regard to growth and development require communication processes - synapse-like communication - between all parts of the plant.

\subsubsection{Intercellular communication}

Short-distance communication differs considerably from long-distance communication. As a rule, both complement each other. Intercellular communication in the root zone (in the soil) differs from that in the stem region above ground. Both are necessarily coordinated with one another in order to enable life in these different habitats. Intercellular communication informs other plant parts about events in specific organs or regions of the plant (especially in large plants), for example sugar production in leaves, the reproduction in flowers and resource utilization by the roots (Xoconostle-Cazares et al. 1999).

Plant cells are connected by specific type of tissue connecting channels ("plasmodesmata") (Samaj et al. 2006). These connecting channels enable the flow of small molecules as well as ions, metabolites and hormones, and allow the selective exchange (size exclusion limit) of macromolecules such as proteins, RNAs and even cell bodies (Baluska et al. 2004 a). The plasmodesmata impart plants with a cytoplasmatic continuum known as the symplasm (Dunoyer and Voinnet 2005). But plasmodesmata are more than mere transport channels; they also regulate and control the exchange of messenger substances in a very complex manner (Gillespie and Oparka 2005). In symplastic signaling, the intercellular communication of plants differs fundamentally from that in other organismic kingdoms (Golz 2005). It integrates various communication types such as local and long-distance communication. Beyond symplastic communication (especially in the meristem, where new tissues are produced), plants also exhibit the receptor-ligand communication typical of animals (Golz 2005). While receptor-ligand communication determines stomatal patterning in the epidermis of mature leaves, trichome patterning is mediated by symplastic signaling (Srinivas and Hülskamp 2005).

For long-distance signaling movement proteins play an important role. Movement proteins convey information, bearing RNA from the stem and leaves, to the remote roots and flowers. The movement protein allows the mRNA to enter the plasmodesmata tunnel, into the phloem flow. Once it has entered this transport system, it can relatively rapidly reach all parts of the plant. These RNAs can control the levels of other proteins. The level contains information for local tissues, for example about the general physical condition of the plant, the season, or the presence of dangerous enemies (Xoconostle-Cazares et al. 1999).

Plasmodesmata are prerequisites for intercellular communication in higher plants (Tassetto et al. 2005). In embryogenesis they are an important information channel between fetal and maternal tissue. The further the development of the embryo, the more reduced the cell-cell communication between embryo and maternal tissue (Kim and Zambryski 2005). Cell-cell communication via direct transmission of transcription factors plays a central role in root radial and epidermal cell patterning as well as in shoot 
organogenesis (Kurata et al. 2005). The cellular organization of the roots is determined during the plant's embryonic development and is controlled by intercellular communication. Bonke et al. (2005) provide a particularly good example of communicative control of these 10 phases of embryogenesis. This confirms the presence of local signaling centers and the complex relationship between numerous different signaling pathways.

A wounded plant organizes an integrated molecular, biochemical and cell biological response. This strategy enables information to be transported across great distances, for example in tall trees (Schilmiller and Howe 2005). Proteins that can be detected by receptors enable a "thoughtful response" (McClintock 1984 ) by plants. There are about one thousand known protein kinases/phosphatases, numerous secondary messengers and many thousands of other proteins (Trewavas 2005). Through their life cycles and their growth zones, plants develop a life history of environmental experience that they can pass on to later generations and, should they themselves grow to be several hundred years old, utilize themselves (Trewavas 2005). Even small plants store stress experiences in their memories and then use these memories to coordinate future activities (Goh et al. 2003). Especially during growth, key information about the current status often takes a back seat to future-oriented processes, for example early root growth and nutrient supply to secure future developments such as larger leaves. From this perspective, plants must plan for the future and coordinate growth, food uptake and communication with symbionts (Trewavas 2003).

The complementary differentiation of communication types into short-distance and long-distance signaling - with their different yet ultimately complementary tasks - requires cells to identify their position. They accomplish this by, among other things, detecting signals from neighboring cells (Coupland 2005). Thus, the identification competence of "self" and "non-self" by cells can be interpreted as a result of social interaction rather than solipsistic behavior. For example, signals from leaves trigger flower development at the tip of a plant (Coupland 2005). An entire network involving 4 different signal pathways regulates this transition from the vegetative to the reproductive phase (Coupland 2005). Most flowers bear closely adjoining male and female reproductive organs. Self-incompatibility is therefore crucial in distinguishing between own (related) and foreign (non-related) pollen. This self-/non-self differentiation ability is promoted by signal processes also used in other plant responses (McCubbin 2005).

\subsubsection{Intracellular communication}

Intracellular communication in plants takes place between the symbiogenetically assimilated unicellular ancestors of the eukaryotic cell, mainly between the cell body and cell periphery. It transforms and transmits external messages into internal messages that exert a direct (epigenetic) influence on the DNA storage medium and trigger genetic processes; this leads to the production of signal molecules that generate a response behavior. Via endocytosis, however, bacteria, viruses and viroids interfere with this intracellular communication and can support, disrupt or even destroy it. Intracellular communication offers viruses the opportunity to integrate certain genetically coded abilities of the host into their own genome or to integrate their own genetic datasets into the host genome. The ability of viruses to integrate different genetic datasets probably plays a major role in symbiogenetic processes.

The eukaryotic cell is composed of a multicompetent nucleus as a basic building block of life and a cell periphery-"apparatus" that was symbiogenetically the ancestor of other endosymbionts. Interestingly, both the nucleus and viruses have several similar features and capabilities: they both lack the protein synthesis "machinery" and the fatty acid-producing pathways. Both transcribe DNA but do not translate it into RNA. Viruses were probably very important in the evolution of eukaryotic cells because they were able to conduct cell-cell "fusion" (Baluska et al. 2005b). There are strong reasons too, that the eukaryotic nucleus is of viral origin (Bell 2001, Ryan 2002, Villarreal 2005).

Neuronal plasticity refers to the ability of neuron populations to alter - to either strengthen or weaken their connections based on experience. This is the basis for learning and memory. Like memory, long-term neuronal plasticity requires new RNA and protein synthesis. Accordingly, the signals must be transported 
from the synapse, from where they are sent, to the nucleus, where they are transformed to change the gene transcription. Then, the products of gene transcription (proteins, RNAs) must be sent back to the synapse in order to permanently change synaptic strength. This communication process is well described in animals (Thompson et al. 2004, Martin 2004, Moccia et al. 2003); if plants exhibit neuronal plasticity, then similar descriptions may follow.

Reports on the transfer of mitochondrial genes between unrelated plant species caused some surprise. While gene transfer is an extremely rare event in animals and fungi, it is common between plant mitochondria (Andersson 2005). Variations in repetitive DNA that manifest themselves as variation in the nuclear DNA complex have far-reaching ecological and life history consequences for plants (Meagher and Vassiliadis 2005).

The function of a eukaryotic cell depends on successful communication between its various parts. Plastids send signals to regulate nuclear gene expression and thus to reorganize macromolecules in response to environmental influences (Strand 2004). It has been shown that micro-RNAs regulate certain developmental processes such as organ separation, polarity and identity, and that they define their own biogenesis and function (Dugas and Bartel 2004). Eukaryotic genomes are regionally divided into transcriptionally active euchromatin and transcriptionally inactive heterochromatin (Bender 2004). Epigenetic changes can also take place without changes in genomes, for example through various inactivations and activations of genetic datasets via chromatin remodeling, transposon/retro release, DNA methylation, novel transcription, histone modification, and transcription factor interactions (Jablonka and Lamb 2002). Epigenetic changes are also reversible (Rapp and Wendel 2005). Various stress situations in plants are known to cause transposon movements (Kumar and Bennetzen 1999), and bacterial infections or UV stress can cause chromosomal rearrangements (Kovalchuk et al. 2003), i.e. changes in higherorder regulation levels that control the transcription processes of the protein-coding DNA. ${ }^{6}$

Endocytosis and vesicle recycling via secretory endosomes are indispensable for many processes in multicellular organisms. Plant endocytosis and endosomes are important for auxin-mediated cell-cell communication as well as for gravitropic responses, stomatal movements, cytokinesis and cell wall morphogenesis. As in animals, synaptic cell-cell communication is based on rapid endocytosis and vesicular recycling in plants (Samaj et al. 2005).

Plants can overwrite the genetic code they inherited from their parents and revert to that of their grand or great-grandparents (Lolle et al. 2005, Weigl and Jürgens 2005, Pearson 2005). This contradicts traditional DNA-textbook conviction that children simply receive combinations of the genes carried by their parents. Now a backup code has been found; it can bypass unhealthy sequences inherited from the parents and revert to the healthier sequences borne by their grandparents or great-grandparents. Research has shown that plants are able to replace abnormal parental code sequences with the regular code possessed by earlier generations. Does this require inheritance not only of the parental genetic make-up but also that of the grand-parents and former ancestors? What is proposed is that higher-order regulation function in non-coding DNA - a type of genome-editing MetaCode (Witzany 2005 a) - save ancestor genome structures, which overrule protein-coding DNA under certain circumstances like stress. This means that the (pragmatic) situational context of the living plant body may induce epigenetic intervention on the genome editing MetaCode, i.e. active micro-RNAs activate a certain signaling pathway network which can restructure the semantics of a genetic make-up. By initiating chromosomal methylation and histone-modifications, certain silencing, start and stops, and alternative splicing processes constitute alternative sequences. The result is that, in the existing genome architecture, not the inherited parental sequences are translated and transcribed but the backup copy of grand or great- grandparents. Under normal conditions, the operative genetic make-up stems from the parents. These research results indicate

\footnotetext{
${ }^{6}$ Repetitive DNA is present in two syntactic combinations: tandem repeats and dispersed repeats. Tandem repeats consist of sequences that can contain several thousand copies of elements that are dispersed throughout the genome. Pericentromeric sequences consist of a central repetitive nucleus flanked by moderately repetitive DNA. Telomeric and subtelomeric sequences consist of tandem repeats at the physical end of the chromosomes. Retroelements and transposable elements are involved in replication and reinsertion at various sites in complex processes: these include activation of excision, DNA-dependent RNA transcription, translation of RNA into functioning proteins, RNA-dependent DNA synthesis (reverse transcription) and reintegration of newly produced retroelement copies into the genome (Meagher and Vassiliadis 2005).
} 
that not only is a combination of parental genes inherited, but also ancestral genome-regulating features in "non-coding" DNA; this enables alternative splicing pathways, i.e. a different use and multiple protein meanings of one and the same genetic data set (Lolle et al. 2005, Weigl and Jürgens 2005, Pearson 2005).

\subsection{Perspectives}

Plants are the youngest organismic kingdom and perhaps the main success story of evolution. They arose around 350 million years ago, and terrestrial plants, which flower and bear fruits (a key prerequisite for feeding in larger animals), only developed 150 million years ago. Higher plants make up 99\% of the biomass on our planet; of this, nearly $84 \%$ are trees. The lack of mobility is often construed as a disadvantage vis-à-vis representatives of the animal kingdom. From an objective perspective, such immobility and the sessile lifestyle must have been an advantage.

Plants fundamentally depend on successful communication. The behavior in the specific interaction can be misinterpreted. A plant can feign mutualism, for example, in order to gain a one-sided advantage from the interaction and to damage, permanently exploit or kill the partner. This, however, cannot be the representative form of communication because no individuals would survive if all plants behaved in this manner. The majority of interactions must be successful for several participants.

Communication processes are successful when the rules governing sign use are correctly followed. Clearly, rules can be broken. In such cases, the messages transmitted via the signs are incomplete, incorrect and induce no or a false behavioral response. Messages can also be misinterpreted: (a) the sign user uses the sign incorrectly/misleadingly, and the message does not arrive in the manner intended and for the envisioned purpose because it is mutilated, fragmentary, and in due course the recipient cannot respond to the message in the manner required by the non-mutilated message; (b) the sign continuously expresses a message that does not conform with reality ('insect enemies are attacking') and the recipient of the message will respond in a manner adapted to the reality of this inconformity; (c) the message is used to mean something other than it is normally used to convey (in order to gain one-sided advantages). Any constant rule-breaking blocks the organization of life processes (communicative coordination of evolution, reproduction, growth, development) within and between organisms.

Integrating this biosemiotic perspective will help us to decipher more gradually the specific meaning of the full range of semiochemicals (in their broader sense) and to become aware of the high-level communicative competences of plants.

\section{General outlook on biocommunication}

In this article I have demonstrated that the life of the organismic kingdoms of bacteria, fungi and plants is far from being a mechanistic process of action and reaction similar to mere physical entities, but organized and coordinated by communication processes. These communication processes function in most cases very conservatively. Because they depend on semiotic rules in addition to natural laws they may even fail or - in some cases - be error-prone. But this flexibility is the precondition for invention, generation, combination or recombination of biosemiotic rules, which enable organisms to use available chemical molecules in a new way, to generate new sequences and new sequence regulations. Living nature depends on functioning semiosis or, as Howard Pattee says, 'Life and the non-living world are distinguished by its dependence on signs' (Pattee 2005).

The communicative competences of organisms of these three organismic kingdoms share common features: they assemble metaorganismic communication, interorganismic communication, intraorganismic (inter and intracellular) communication. Additionally, any organism is able to distinguish whether the received chemical molecules represent (i) a biotic message (Mitwelt), (ii) an indicator of abiotic environment (Umwelt) or (iii) 'noise', have no biosemiotic feature (Witzany 2006 b).

Additional to the semiotic rules of biocommunication (i.e. rule-governed sign-mediated interactions) biosemiotics also investigates the linguistic features of natural genetic engineering and natural genome- 
editing. This is a crucial difference, because (1) the semiotic rules that determine the sign use to generate a context-specific behavior ( e.g. (i) mating, attack, defense, monitoring, nutrition uptake and most of all (ii) the coordination within the organism and between organisms of the same or related or unrelated species) and (2) the semiotic rules that determine the generation, combination, recombination or insertion of correct nucleic acid sequences have completely different need of competence: This means, communicative interaction between organisms is a different context from that of correct editing of nucleic acid sequences, as I have outlined elsewhere (Witzany $2007 \mathrm{~b}$ ).

Successful biosemiotic processes are therefore the precondition for both living organisms (individuals are able to coordinate their behavior) and for all editorial processes in the nucleic acid language, i.e. the genomic content. Without biosemiotic processes prokaryotic organisms could not coordinate their behavior like a multicellular organism, nor could real multicellular organisms like animals, fungi and plants live without rule-governed sign-mediated interactions between the cells of their body, nor could multicellular organisms coordinate their behavior. These sign-mediated coordinations normally function error-free, but under certain circumstances like mechanical damage, extreme heat or other stressful influences may even fail, which means normal function of cells, tissues, organs and organisms doesn't occur, with potentially fatal consequences for the organism(s).

A three-leveled biosemiotics may be an essential part of a twenty-first century biology which is not restricted to reductionism and mechanism and therefore is able to integrate the broad variety of new empirical data which do not reflect mechanistic features but an unforeseeable complexity of sign-mediated interactions.

\section{References}

Adachi, K./Hamer, J.E. (1998) Divergent cAMP signalling pathways regulate growth and pathogenesis in the rice blast fungus Magnaporthe grisea. In: Plant Cell Vol. 10, pp 1361-1374.

Alspaugh, A.J./Cavallo, L.M./Perfect, J.R./Heitman, J. (2000) Ras1 regulates filamentation, mating and growth at high temperature of Cryptococcus neoformans. In: Molecular Microbiology, Vol. 36, pp 352-365.

Amzallag, N.G. (2002) Brassinosteroids as metahormones: evidences from specific influence during critical period in Sorghum development. In: Plant Biology (Stuttg) Vol. 4, pp 656-663.

Andersson, J. (2005) Lateral gene transfer in eukaryotes. In: Cellular and Molecular Life Sciences, Vol. 62, pp 1182-1197.

Apel, K./Hirt, H. (2004) Reactive oxygen species: metabolism, oxidative stress, and signal transduction. In: Annual Review of Plant Biology, Vol. 55, pp 373-99.

Arora, D.K. (2003) Handbook of Fungal biotechnology. New York. Marcel Dekker

Bais, H.P./Park, S.W./Weir, T.L./Callaway, R.M./Vivanco, J.M. (2003) How plants communicate using the underground information superhighway. In: Trends in Plant Science, Vol. 9, pp 26-32.

Ballare, C.L. (1999) Keeping up with the neighbours: phytochrome sensing and other signalling mechanisms. In: Trends in Plant Science, Vol. 4, pp 97-102.

Baluska, F./Volkmann, D./Barlow, P.W. (2004a) Eukaryotic Cells and their Cell Bodies: Cell Theory Revised. In: Annals of Botany, Vol. 94, pp 9-32.

Baluska, F./Mancuso, S./Volkmann, D./Barlow, P.W. (2004b) Root apices as plant command centres: the unique, 'brain-like' status of the root apex transition zone. In: Biologia (Bratislava), Vol. 59, pp 7-19.

Baluska, F./Volkmann, D./Barlow, P.W. (2005a) Cell-Cell Channels and Their Implications for Cell Theory. In: Baluska, F./Volkmann D./ Barlow, P.W. (Eds.) Cell-Cell Channels. Eurekah.com, 1-17.

Baluska, F./Volkmann, D./Menzel, D. (2005b) Plant synapses: actin-based domains for cell-to-cell communication. In: Trends in Plant Science, Vol. 10, pp 106-111.

Baluska, F./Volkmann, D./Hlavacka, A./Mancuso, S./Barlow, P.W. (2006) Neurobiological View of Plants and Their Body Plan. In: Baluska, F./Mancuso, S./Volkmann, D. (Eds.) Communication in Plants. Berlin/Heidelberg: Springer. pp 19-35.

Banuett, F. (1998) Signalling in the yeasts: an informational cascade with links to the filamentous fungi. In: Microbiology and Molecular Biology Reviews, Vol. 62, pp 249-274.

Bardwell, L. (2004) A walk-through of the yeast mating pheromone response pathway. In: Peptides, Vol. 25, pp 1465-1476.

Bassler, B.L. (1999) How bacteria talk to each other: Regulation of gene expression by quorum sensing. In: Current Opinion in Microbiology, Vol. 2, pp 582-587.

Bassler, B.L. (2002) Small talk: cell-to-cell communication in bacteria. In: Cell, Vol. 109, pp 421-424.

Batut, J./Andersson S.G.E./O'Callaghan, D. (2004) The evolution of chronic infection strategies in the a-proteobacteria. In: Nature Review of Microbiology, Vol. 2, pp 933-945. 
Bauer, W.D./Robinson, J.B. (2002) Disruption of bacterial quorum sensing by other organisms. In: Current Opinion in Biotechnology, Vol. 13, pp 234-237.

Beck, T./Hall, M.N. (1999) The TOR signaling pathway controls nuclear localization of nutrient-regulated transcription factors. In: Nature, Vol. 402, pp 689-92.

Bell, P. (2001) Viral eukaryogenesis: was the ancestor of the nucleus a complex DNA virus? In: Journal of Molecular Evolution, Vol. 53, pp 251-256.

Bell-Pederson, D./Dunlap J.C./Loros J.J. (1996) Distinct cis-acting elements mediate clock, light, and developmental regulation of the Neurospora crassaeas (ccg2)gene. In: Molecular and Cellular Biology, Vol. 16, pp 513-521.

Belozerskaya, T.A. (1998) Cell-to-cell Communication in differentiation of mycelial fungi. In: Membrane Cell Biology, Vol. 11, pp 831840.

Bender, J. (2004) Chromatin-based silencing mechanisms. In: Current Opinion in Plant Biology, Vol. 7, pp 521-526.

Ben Jacob, E. (2003) Bacterial self-organization: co-enhancement of complexification and adaptability in a dynamic environment. In: Philosophical Transactions of the Royal Society A, Vol. 361, pp 1283-1312.

Ben Jacob, E./Becker I./Shapira, Y./Levine, H. (2004) Bacterial linguistic communication and social intelligence. In: Trends in Microbiology, Vol. 12, pp 366-372.

Ben Jacob, E./Levine, H. (2006) Self-engineering capabilities of bacteria. In: Journal of the Royal Society Interface, Vol. 3, pp 197214.

Berg, O.G./Kurland, C.G. (2002) Evolution of Microbial Genomes: Sequence Acquisition and Loss. In: Molecular Biology and Evolution, Vol. 19, pp 2265-2276.

Bhabhra, R./Zhao, W./Rhodes, J.C./Askew, D.S. (2006) Nucleolar localization of aspergillus fumigatus CgrA is temperaturedependent. In: Fungal Genetics and Biology, Vol. 43, pp 1-64.

Blech, J. (2000) Leben auf dem Menschen. Die Geschichte unserer Besiedler. Hamburg. Rowohlt Taschenbuch Verlag.

Bonke, M./Tähtiharju, S./Helariutta, Y. (2005) Lessons from the root apex. In: Fleming, A.J. (ed.) Intercellular Communication in Plants. Annual Plant Reviews. Oxford. Blackwell Publishing Vol. 16, pp 199-223.

Bordenstein, S.R./Reznikoff, W.S. (2005) Mobile DNA in obligate intracellular bacteria. In: Nature Reviews Microbiology, Vol. 3, pp 688-699.

Borges-Walmsley, I.M./Walmsley, A.R. (2000) CAMP signalling in pathogenic fungi: control of dimorphic switching and pathogenicity. In: Trends in Microbiology, Vol. 8, pp 133-141.

Braam, J. (2005) In touch: plant responses to mechanical stimuli. In: New Phytologist, Vol. 165, pp 373-389.

Brown, J.R. (2003) Ancient horizontal gene transfer. In: Nature Review Genetics, Vol. 4, pp. 122-132.

Brundrett, M.C. (2002) Coevolution of roots and mycorrhizas of land plants. In: New Phytologist, Vol. 154, pp 275-304.

Buckley, T.N. (2005) The control of stomata by water balance. In: New Phytologist, Vol. 168, pp 275-292.

Callaway, R.M. (2002) The detection of neighbors by plants. In: Trends in Ecology and Evolution, Vol. 17, pp 104-105.

Camara, M./Williams, P./Hardman, A. (2002) Controlling infection by tuning in and tuning down the volume of bacterial small-talk. In: The Lancet Infectious Diseases, Vol. 2, pp 667-676.

Campanoni, P./Blasius, B./Nick, P. (2003) Auxin transport synchronizes the pattern of cell division in a tobacco cell line. In: Plant Physiology, Vol. 133, pp 1251-60.

Carol, R.J./ Dolan, L. (2006) The role of reactive oxygen species in cell growth: lessons from root hairs. In: Journal of Experimental Botany, Vol. 57, pp 1829-34.

Casadevall, A. (2006) Fungal virulence, vertebrate endothermy, and dinosaur extinction: is there a connection? In: Fungal Genetics and Biology, Vol. 42, pp 98-106.

Casson, S.A./Lindsey, K. (2003) Genes and signalling in root development. In: New Phytologist, Vol. 158, pp 11-38.

Cornelius, M.L./Bland, J.M./Daigle, D.J./Williams, K.S./Lovisa, M.P./Connick, W.Jr./Lax, A.R. (2004) Effect of a Lignin-Degrading Fungus on Feeding Preferences of Formosan Subterranean Termite (Isoptera: Rhinotermitidae) for Different Commercial Lumber. In: Journal of Economic Entomology, Vol. 97, pp 1025-1035.

Coupland, G. (2005) Intercellular communication during floral initiation and development. In: Fleming, A.J. (Ed.) Intercellular Communication in Plants. Annual Plant Reviews, Oxford. Blackwell Publishing, Vol. 16, pp 178-197.

Crespi, B.J. (2001) The evolution of social behaviour in microorganisms. In: Trends in Ecology and Evolution, Vol. 16, pp 178-183.

Crespo, J.L./Hall, M.N. (2002) Elucidating TOR signalling and rapamycin action: lessons from Saccharomyces cerevisiae. In: Microbiology and Molecular Biology Reviews, Vol. 66, pp 579-591.

Cutler, S.N./Pan, X.W./Heitman, J./Cardenas, M.A. (2001) The TOR Signal Transduction Cascade controls cellular differentiation in response to nutrients. In: Molecular Biology of the Cell, Vol. 12, pp 4103-4113.

Daniels, R./Vanderleyden, J./Michiels, J. (2004) Quorum sensing and swarming migration in bacteria. In: FEMS Microbiology Reviews, Vol. 28, pp 261-289.

Davis, D.G./Parsek, M.R./Pearson, J.P./Iglewski, B.H./Costerton, J.W./Greenberg, P.E. (1998) The involvement of cell-to-cell signals in the development of a bacterial biofilm. In: Science, Vol. 280, pp 295-298.

Defeu-Soufo, H.J./Graumann, P.L. (2004) Dynamic movement of actin-like proteins within bacterial cells. EMBO Reports, Vol. 5, pp 789-794.

Delledonne, M. (2005) NO news is good news for plants. In: Current Opinion in Plant Biology, Vol. 8, pp 390-396. 
Denison, F.R./Kiers, T.E. (2004) Why are most rhizobia beneficial to their plants, rather than parasitic? In: Microbes and Infection, Vol. 6, pp 1235-1239.

Dessaux, Y. (2004) Biological Communications and Interactions in the Rhizosphere. Presented at "Rhizosphere 2004"-congress, 12. 17. September 2004, Munich/Germany.

Dix, N.J./Webster, J. (1995) Fungal Ecology. London. Chapman \& Hall

Dohlman, H.G. (2002) G proteins and pheromone signalling. In: Annual Review of Physiology, Vol. 64, pp 129-151.

D'Souza, C.A./Heitman, J. (2001) Conserved cAMP signalling cascades regulate fungal development and virulence. In: FEMS Microbiology Reviews, Vol. 25, pp 349-364.

Dugas, D.V./Bartel, B. (2004) MicroRNA regulation of gene expression in plants. In: Current Opinion of Plant Biology, Vol. 7, pp 512-520.

Dunlap, J.C./Loros, J.J./Denault, D./Lee, K./Froelich, A./Colot, H./Shi, M./Preguero, A. (2004) Genetics and molecular biology of circadian rhythms. In: Brambl, R./Marzluf, G.A. (Eds.) The Mycota III. Biochemistry and Molecular Biology, Second Edition, Berlin/Heidelberg. Springer, pp 209-229.

Dunn, A.K./Handelsman, J. (2002) Toward an understanding of microbial communities through analysis of communication networks. In: Antonie van Leeuwenhoeck, Vol. 81, pp 565-574.

Dunoyer, P./Noinnet, O. (2005a) The complex interplay between plant viruses and host RNA-silencing pathways. In: Current Opinion in Plant Biology, Vol. 8, pp 415-423.

Dunoyer, P./Voinnet, O. (2005b) RNA as a signalling molecule. In: Fleming AJ. (Ed.) Intercellular Communication in Plants. Annual Plant Reviews. Oxford. Blackwell Publishing, Vol. 16, pp 49-83.

Engelberth, J./Alborn, H.T./Schmelz, E.Y./Tumlinson, J.H. (2004) Airborne signals prime plants against insect herbivore attack. In: Proceedings of the National Academy of Sciences of the U S A, Vol. 101, pp 1781-1785.

Ercan, S./Lieb, J.D. (2006) New evidence that DNA encodes its packaging. In: Nature Genetics, Vol. 38, pp 1104-1105.

Estabrock, E.M./Yoder, J.I. (1998) Plant-plant communications: rhizosphere signalling between parasitic angiosperms and their hosts. In: Plant Physiology, Vol. 116, pp 1-7.

Farmer, E./Schulze-Lefert, P. (2005) Biotic interactions: From molecular networks to inter-organismal communities. In: Current Opinion in Plant Biology, Vol. 8, pp 343-345.

Federle, M.J./Bassler, B.L. (2003) Interspecies communication in bacteria. In: The Journal of Clinical Investigations, Vol. 112, pp 1291-1299.

Fernandes, L./Araujo, M.M./Amaral, A./Reis, V.B./Martins, N.F./Felipe, M.S. (2005) Cell signalling pathways in Paracoccidioides brasiliensis - inferred from comparism with other fungi. In: Genetics and Molecular Research, Vol. 4, pp 216-231.

FGSC- Fungal Genetics Stock Center (2005) The Neurospora Homepage. http://www.fgsc.net/

Fleming, A.J. (2005) The plant extracellular matrix and signalling. In: Fleming, A.J. (Ed.) Intercellular Communication in Plants. Annual Plant Reviews. Oxford. Blackwell Publishing, Vol. 16, pp 85-107.

Flores, H.E./Vivanco, J.M./Loyola-Vargas, V.M. (1999) 'Radicale' biochemistry: the biology of root-specific metabolism. In: Trends in Plant Science, Vol. 4, pp 220-226.

Friml, J./Wisniewska, J. (2005) Auxin as an intercellular signal. In: Fleming, A.J. (Ed.) Intercellular Communication in Plants. Annual Plant Reviews. Oxford. Blackwell Publishing, Vol. 16, pp 1-26.

Fuqua, C./Winians, S.C./Greenberg, P.E. (1996) Census and consensus in bacterial ecosystems: the LuxR-LuxI family of quorumsensing transcriptional regulators. In: Annual Review of Microbiology, Vol. 50, pp 727-751.

Fuqua, C./Greenberg, P.E. (2002) Listening in on bacteria: acylhomoserine lactone signalling. In: Nature Reviews Molecular Cell Biology, Vol. 3, pp 685-695.

Gillespie, T./Oparka, K.J. (2005) Plasmodesmata - gateways for intercellular communication in plants. In: Fleming, A.J. (Ed.) Intercellular Communication in Plants. Annual Plant Reviews. Oxford. Blackwell Publishing, Vol. 16, pp 109-146.

Glass, L.N./Jacobson, D.J./Shiu, P.T. (2000) The Genetics of Hyphal Fusion and Vegetative Incompatibility in filamentous ascomycete Fungi. In: Annual Review of Genetics, Vol. 34, pp 165-186.

Glass, L.N./Saupe, S.J. (2002) Vegetative incompatibility in filamentous ascomycetes. In: Osiewacz, H.D. (Ed.) Molecular Biology of Fungal Development. New York. Marcel Dekker, pp 109-131.

Glass, L.N./Kaneko I. (2003) Fatal Attraction: Nonself Recognition and Heterokaryon Incompatibility in Filamentous Fungi. In: Eukaryotic Cell, Vol. 2, pp 1-8.

Gogarten, P.J./Townsend, J.P. (2005) Horizontal gene transfer, genome innovation and evolution. In: Nature Reviews Microbiology, Vol. 3, pp 679-687.

Goh, C.H./Nam, H.G./Park, Y.S. (2003) Stress memory in plants: a negative regulation of stomatal response and transient induction of rd22 gene to light in abscisic acid-entrained Arabidopsis plants. In: Plant Journal, Vol. 36, pp 240-255.

Golz, J.F. (2005) Lessons from the vegetative shoot apex. In: Fleming, A.J. (Ed.) Intercellular Communication in Plants. Annual Plant Reviews. Oxford. Blackwell Publishing, Vol. 16, pp 147-177.

Graumann, P.L. (2004) Cytoskeletal elements in bacteria. In: Current Opinion in Microbiology, Vol. 7, pp 565-571.

Graumann, P.L./Defeu-Soufo, H.J. (2004) An intracellular actin motor in bacteria? In: Bioessays, Vol. 26, pp 1209-1216.

Greenberg, P.E. (2003) Bacterial communication: tiny teamwork. In: Nature, Vol. 424, p 134.

Griffin, D.H. (1994) Fungal Physiology. Second Edition, New York. Wiley-Liss. 
Guerts, R./Fedorova, E./Bisseling, T. (2005) Nod factor signalling genes and their function in the early stages of Rhizobium infection. In: Current Opinion in Plant Biology, Vol. 8, pp 346-352.

Hartmann, A./Kahmann, R./Bölker, M. (1996) The pheromone response factor coordinates filamentous growth and pathogenicity in Ustilago maydis. In: EMBO Journal, Vol. 15, pp 1632-41.

Hartmann, A.H./Krüger, J./Lottspeich, F./Kahmann, R. (1999) Environmental Signals Controlling sexual development of the Corn Smut Fungus Ustilago maydis through the transcriptional Regulator Prf1. In: The Plant Cell, Vol. 11, pp 1293-1305.

Hellmeier, H./Erhard, M./Schulze, E.D. (1997) Biomass accumulation and water use under arid conditions. In: Bazzaz, F.A./ Grace, J. (Eds.) Plant Resource Allocation. London. Academic Press, pp 93-113.

Hemenway, C.S./Heitman, J. (1999) Calcineurin: structure, function, and inhibition. In: Cell Biochemy and Biophysics, Vol. 30, pp 115-151.

Henke, J.M./Bassler, B.L. (2004) Bacterial social engagements. In: Trends in Cell Biology, Vol. 14, pp 648-656.

Hirsch, A.M./Bauer, D.W./Bird, D.M./Cullimore, J./Tyler, B./Yoder, J.I. (2003) Molecular signals and receptors: controlling rhizosphere interacting between plants and other organisms. In: Ecology, Vol. 84, pp 858-868.

Hoffman, C.S. (2005) Except in every detail: comparing and contrasting G-Protein signalling in Saccharomyces cerevisiae and Schizosaccharomyces pombe. In: Eukaryotic Cell, Vol. 4, pp 495-503.

Hogan, D.A. (2006) Talking to Themselves: Autoregulation and Quorum Sensing in Fungi. In: Eukaryotic Cell, Vol. 584, pp 613-619. Imaizumi-Anraku, H./Takeda, N./Cherpentier, M./Perry, J./Miwa, H./Umehara, Y./Kouchi, H./Murakami, Y./Mulder, L./Vickers, K./Pike, J./Downie, A./Wang, T./Sato, S./Asamizu, E./Tabata, S./Yoshikawa, M./Murooka, Y./Wu, G.J./Kawaguchi, M./Kawasaki, S./Parniske M./Hayashi, M. (2005) Plastid proteins crucial for symbiotic fungal and bacterial entry into plant roots. In: Nature, Vol. 433, pp 527-531.

Jablonka, E./Lamb, M.J. (2002) The Changing Concept of Epigenetics. In: Annals of the New York Academy of Sciences, Vol. 981, pp 82-96.

Jain, R./Rivera, M.C./Lake, J.A. (1999) Horizontal gene transfer among genomes: The complexity hypothesis. In: Evolution, Vol. 96, pp 3801-3806.

Jain, R./Rivera, M.C./Moore, J.E./Lake, J.A. (2003) Horizontal Gene Transfer accelerates genome innovation and evolution. In: Molecular Biology and Evolution, Vol. 20, pp 1598-1602.

Jakupovic, M./Heintz, M./Reichmann, P./Mendgen, K./Hahn, M. (2006) Microarray analysis of expressed sequence tags from haustoria of the rust fungus Uromyces fabae. In: Fungal Genetics and Biology, Vol. 43, pp 8-19.

Jorgensen, R. (1993) The origin of land plants: a union of alga and fungus advanced by flavenoids. In: BioSystems, Vol. 31, pp 193207.

Jorgensen, R. (2004) Restructuring the Genome in response to Adaptive Challenge: McClintock's Bold Conjecture Revisited. In: Cold Spring Harbor Symposia on Quantitative Biology, Vol. 69, pp 349-354.

Kahmann, R./Basse, C. (2001) Fungal gene expression during pathogenesis-related development and host plant colonization. In: Current Opinion in Microbiology, Vol. 4, pp 374-380.

Kaiser, D.Melch, R. (2004) Dynamics of fruiting body morphogenesis. In: Journal of Bacteriology, Vol. 186, pp 919-927.

Kant, M.R./Ament, K./Sabelis, M.W./Haring, M.A./Schuurink, R.C. (2004) Differential Timing of Spider Mite-Induced Direct and Indirect Defenses in Tomato Plants. In: Plant Physiology, Vol. 135, pp 483-495.

Kays, A.M./Borkovich, K.A. (2004) Signal transduction pathways mediated by heterotrimeric G proteins. In: Brambl, R./Marzluf, G.A. (Eds.) The mycota III, Berlin. Springer, pp 175-207.

Keller, L./Surette, M.G. (2006) Communication in bacteria: an eco-logical and evolutionary perspective. In: Nature Reviews Microbiology, Vol. 4, pp 249-258.

Kellis, M./Patterson, N./Endrizzi, M./Birren, B./Lander, E.S. (2003) Sequencing and comparism of yeast species to identify genes and regulatory elements. In: Nature, Vol. 423, pp 241-54.

Kellis, M./Birren, B./Lander, E.S. (2004) Proof and evolutionary analysis of ancient genome duplication in the yeast Saccharomyces cerevisiae. In: Nature, Vol. 428, pp 617-24.

Keyes, J.W./O'Malley, R.C./Kim, D./Lynn, D.G. (2000) Signalling Organogenesis in Parasitic Angiosperms: Xenognosin Generation, Perception, and Response. In: Journal of Plant Growth Regulation, Vol. 19, pp 217-231.

Kidner, C.A./Martienssen, R.A. (2005) The developmental role of micro RNA in plants. In: Current Opinion in Plant Biology, Vol. 8, pp 38-44.

Kiers, T.E./Rousseau, R.A./West, S.A./Denison, F.R. (2003) Host sanctions and the legume-Rhizobium mutualism. In: Nature, Vol. 425, pp 78-81.

Kim, I./Zambryski, P.C. (2005) Cell to-cell communication via plasmodesmata during Arabidopsis embryogenesis. In: Current Opinion in Plant Biology, Vol. 8, pp 593-599.

Kohlenbrander, P.E./Andersen, R.N./Blehert, D.S./Egland, P.G./Foster, J.S./Palmer, R.J. (2002) Communication among Oral Bacteria. In: Microbiology and Molecular Biology Reviews, Vol. 66, pp 486-505.

Kohlenbrander, P.E./Egland, P.G./Diaz, P.I./Palmer, R.J. (2005) Genome-genome interactions: bacterial communities in initial dental plaque. In: Trends in Microbiology, Vol. 13, pp 11-15.

Konaklieva, M.I./Plotkin, B.J. (2006) Chemical communication - do we have a quorum? In: Mini Reviews in Medical Chemistry, Vol. 6, pp 817-825. 
Kopper, B.J./Klepzig, K.D./Raffa, K.F. (2004) Components of Antagonism and Mutualism in Ips pini - Fungal interactions: relationship to a Life History of colonizing Highly Stressed and Dead Trees. In: Environmental Entomology, Vol. 33, pp 28-34.

Kovalchuk, I./Kovalchuk, O./Kalck, V./Boyko, V./Filkovski, J./Heinlein, M./Hohn B. (2003) Pathogen-induced systemic plant signal triggers DNA rearrangements. In: Nature, Vol. 423, pp 760-762.

Krampen, M. (1981) Phytosemiotics. In: Semiotica, Vol. 36, pp 187-209.

Kreft, J.U. (2004) Biofilms promote altruism. In: Microbiology, Vol. 150, pp 2751-2760.

Kroes, I./Lepp, P.W./Relman, D.A. (1999) Bacterial diversity within the human subgingival crevice. In: Proceedings of the National Academy of Sciences of the U S A, Vol. 96, pp 14547-14552.

Krüger, J./Loubradou, G./Regemfelder, E./Hartmann, A./Kahmann, R. (1998) Crosstalk between cAMP and pheromone signaling pathways in Ustilago Maydis. In: Molecular and General Genetics, Vol. 260, pp 193-198.

Kumar, A./Bennetzen, J.L. (1999) Plant retrotransposons. In: Annual Review Genetics, Vol. 33, pp 479-532.

Kunin, V./Goldovsky, L./Darzentas, N./Ouzounis, C.A. (2005) The net of life: Reconstructing the microbial phylogenetic network. In: Genome Research, Vol. 15, pp 954-959.

Kurata, T./Okada, K.Mada, T. (2005) Intercellular movement of transcription factors. In: Current Opinion in Plant Biology, Vol. 8, pp 619-624.

Lammers, P.J. (2004) Symbiotic signalling: new functions for familiar proteins. In: New Phytologist, Vol. 16, pp 324-326.

Lang, B.F./O'Kelly, C./Nerad, T./Gray, M.W./Burger, G. (2002) The closest unicellular relatives of animals. In: Current Biology, Vol. 12, pp 1773-1778.

Lengeler, K.B./Davidson, R.C./D'Souza, C./Harashima, T./Shen, W.C./Wang, P./Pan, X./Waugh, M./Heitman, J. (2000) Signal Transduction cascades regulating Fungal Development and Virulence. In: Microbiology and Molecular Biology Reviews, Vol. 64, pp 746-785.

Lenz, D.H./Mok, K.C./Lilley, B.N./Kulkarni, R.V./Wingreen N.S./Bassler, B.L. (2004) The small RNA Chaperone Hfq and multiple small RNAs control quorum sensing in vibrio harveyi and vibrio cholerae. In: Cell, Vol. 118, pp 69-82.

Loh, J./Pierson, E.A./Pierson, L.S.3 ${ }^{\text {rd }}$./Stacey, G./Chatterie, A. (2002) Quorum sensing in plant associated bacteria. In: Current Opinion in Plant Biology, Vol. 5, pp 285-290.

Lolle, S.J./Victor, J.L./Young, J.M./Pruitt, R.E. (2005) Genome-wide non-mendelian inheritance of extra-genomic information in Arabidopsis. In: Nature, Vol. 434, pp 505-509.

Manefield, M./Turner, S.L. (2002) Quorum sensing in context: out of molecular biology and into microbial ecology. In: Microbiology , Vol. 148, pp 3762-3764.

Margulis, L./Schwartz, K.V. (1988). Five Kingdoms. New York. W. H. Freeman and Company

Margulis, L. (1996) Archaeal-eubacterial mergers in the origin of Eukarya: Phylogenetic classification of life. In: Proceedings of the National Academy of Sciences of the USA, Vol. 93, pp 1071-1076.

Margulis, L. (1999) Die andere Evolution. Heidelberg. Spektrum Akademischer Verlag.

Margulis, L. (2004) Serial endosymbiotic theory (SET) and composite individuality. Transition from bacterial to eukaryotic genomes. In: Microbiology Today, Vol. 31, pp 173-174.

Margulis L, Sagan D. (2002) Acquiring Genomes. A Theory of the Origin of Species. New York: Basic Books.

Martin, K.C. (2004) Local Protein Synthesis during Axon Guidance and Synaptic Plasticity. In: Current Opinion in Neurobiology, Vol. 14, pp 305-310.

Mauch-Mani, B./ Mauch, F. (2005) The role of abscisic acid in plant pathogen interactions. In: Current Opinion in Plant Biology, Vol. 8, pp 409-423.

McClintock, B.(1984) The significance of responses of the genome to challenge. In: Science, Vol. 226, pp 792-801.

McCubbin, A.G. (2005) Lessons in signalling in plant self-incompatibility systems. In: Fleming, A.J. (Ed.) Intercellular Communication in Plants. Annual Plant Reviews. Oxford. Blackwell Publishing, Vol. 16, pp 240-275.

McNab, R./ Lamont, R.J. (2003) Microbial dinner-party conversations. The role of LuxS interspecies communication. In: Journal of Medical Microbiology, Vol. 52, pp 541-545.

Meagher, T.R./Vassiliadis, C. (2005) Phenotypic impacts of repetitive DNA in flowering plants. In: New Phytologist, Vol. 168, pp 7180.

Mitchell, T.K./Dean, R.A. (1995) The cAMP-dependent protein kinase catalytic subunit is required for appressorium formation and pathogenesis by the rice blast pathogen Magnaporthe grisea. In: Plant Cell, Vol. 7, pp 1869-1878.

Mithöfer, A./Wanner, G./Boland, W. (2005) Effects of Feeding Spodoptera littoralis on Lima Bean Leaves. II. Continuous Mechanical Wounding Resembling Insect Feeding Is Sufficient to Elicit Herbivory-Related Volatile Emission. In: Plant Physiology, Vol. 137, pp 1160-1168.

Moccia, R./Chen, D./Lyles, V./Kapuya, E.E.Y./Kalachikov, S./Spahn, C.M.T./Frank, J./Kandel, E.R./Barad, M./Martin, K.C. (2003) An unbiased cDNA library prepared from isolated Aplysia sensory neuron processes is enriched for cytoskeletal and translational mRNAs. In: Journal of Neuroscience, Vol. 23, pp 9409-9417.

Moore, W.E.C./Moore, L.V.H. (1994) The bacteria of periodontal diseases. In: Periodontology 2000, Vol. 5, pp 66-77.

Morita, M.T./Tasaka, M. (2004) Gravity sensing and signaling. In: Current Opinion in Plant Biology, Vol. 7, pp 712-718.

NIAID (National Institute of Allergy and Infectious Diseases) (1993) Molecular Medical Mycology SECRETION. In: Proceedings of the NIAID Workshop in Medical Mycology. University of Minnesota, Minneapolis, http://www3.niaid.nih.gov/

Noeth, W. (2000) Handbuch der Semiotik. Stuttgart/Weimar. Metzler. 
Nomura, K./ Melotto, M./He, S.Y. (2005) Suppression of host defense in compatible plant-Pseudomonas syringae interactions. In: Current Opinion in Plant Biology, Vol. 8, pp 361-368.

Nürnberger, T./Brunner, F./Kemmerling, B./Piater, L. (2004) Innate immunity in plants and animals: striking similarities and obvious differences. In: Immunological Review, Vol. 198, pp 249-266.

Pal, C./Papp, B./Lercher, M.J. (2005) Adaptive evolution of bacterial metabolic networks by horizontal gene transfer. In: Nature Genetics, Vol. 37, pp 1372-1375.

Pare, P.W./Tumlinson, J.H. (1999) Plant Volatiles as a Defense against Insect Herbivores. In: Plant Physiology, Vol. 121, pp 325331.

Parsek, M.R./Greenberg, E.P. (2005) Sociomicrobiology: the connections between quorum sensing and biofilms. In: Trends in Microbiology, Vol. 13, pp 27-33.

Paster, B.J./Boches, S.K./Galvin, J.L./Ericson, R.E./Lau, C.N./Levanos, V.A./Sahasrabudhe, A./Dewhirst, F.E. (2001) Bacterial diversity in subgingival plaque. In: Journal of Bacteriology, Vol. 183, pp 3770-3783.

Pattee, H.H. (2005) The Physics and Metaphysics of Biosemiotics. In: Journal of Biosemiotics, Vol. 1, pp 281-301.

Peak, D./West, J.D./Messinger, S.M./Mott, K.A. (2004) Evidence for complex collective dynamics and emergent-distributed computation in plants. In: Proceedings of the National Academy of Sciences of the U S A, Vol. 101, pp 981-922.

Pearce, G./Ryan, CA. (2003) Systemic signalling in tomato plants for defense against herbivores: isolation and characterization of three novel defense-signalling glycopeptide hormones coded in a single precursor gene. In: Journal of Biological Chemistry, Vol. 278, pp 30044-30050.

Pearson, H. (2005) Cress overturns textbook genetics. In: Nature, Vol. 434, pp 351-360.

Poulsen, M./Boomsma, J.J. (2005) Mutualistic Fungi Control Crop Diversity in Fungus-Growing Ants. In: Science, Vol. 307, pp 741744.

Prusty R, Grisafi P, Fink GR. (2004) The plant hormone indoleacetic acid induces invasive growth in Saccharomyces cerevisiae. Proceedings of the National Academy of Sciences of the USA 101: 4153-4157.

Rapp, R.A./Wendel, J.F. (2005) Epigenetics and plant evolution. In: New Phytologist, Vol. 168, pp 81-91.

Raven, J.A. (2002) Selection pressures on stomatal evolution. In: New Phytologist, Vol. 153, pp 371-386.

Reynolds, T.B./Fink, G.R. (2001) Bakers' yeast, a model for fungal biofilm formation. In: Science, Vol. 291, pp 806-807.

Rice, S.A./Givskov, M.C./Steinberg, P./Kjelleberg, S. (1999) Bacterial signals and antagonists: the interaction between bacteria and higher organisms. In: Journal of Molecular Microbial Biotechnology, Vol. 1, pp 23-31.

Rickard, A.H./Palmer, R.J.jr./Blehert, D.S./Campagna, S.R./Semmelhack, M.F./Egland, P.G./Bassler, B.L./Kolenbrander, P.E. (2006) Autoinducer 2: a concentration-dependent signal for mutualistic bacterial biofilm growth. In: Molecular Microbiology, Vol. 60, pp 1446-1456.

Rivera, M.C./Lake, J.A. (2004) The ring of life provides evidence for a genome fusion origin of eukaryotes. In: Nature, Vol. 431, pp 152-155.

Rohde, J.R./Cardenas, M.E. (2004) Nutrient signalling through TOR kinases controls gene expression and cellular differentiation in fungi. In: Current Topics in Microbiology and Immunology, Vol. 279, pp 53-72.

Romero, G.Q./Benson, W.W. (2005) Biotic interactions of mites, plants and leaf domatia. In: Current Opinion in Plant Biology, Vol. 8, pp 436-440.

Roossinck, M.J. (2005) Symbiosis Versus Competition in Plant Virus Evolution. In: Nature Reviews Microbiology, Vol. 3, pp 917-924. Ryan, F. (2002) Darwin's blind spot: evolution beyond natural selection. Boston. Houghton Mifflin Company.

Ryan, F. (2006) Genomic creativity and natural selection: a modern synthesis. Biological Journal of the Linnean Society, Vol. 88, pp $655-672$

Samaj, J./Baluska, F./Voigt, B./Schlicht, M./Volkmann, D./Menzel, D. (2004) Endcytosis, Actin Cytoskeleton, and Signalling. In: Plant Physiology, Vol. 135, pp 1150-1161.

Samaj, J./Read, N.D./Nolkmann, D./Menzel, D./Baluska, F. (2005) The endocytic network in plants. In: Trends in Cell Biology, Vol. 15, pp 425-433.

Samaj, J./Chaffey, N./Tirlapur, U./Jasik, J./Hlavacka, A./Cui, Z.F./Volkmann, D./Menzel, D./Baluska, F. (2006) Actin and Myosin VIII in Plant Cell-Cell Channels. In: Baluska, F./Volkmann, D./Barlow, P.W. (Eds.) Cell-Cell-Channels. Georgetown. Landes BioScience, pp 119-134.

Sanders, W,B. (2001) Lichens: the interface between mycology and plant morphology. In: BioScience, Vol. 51, pp 1025-1035.

Sanders, W.B. (2006) A feeling for the superorganism: expression of plant form in the lichen thallus. In: Botanical Journal of the Linnean Society, Vol. 150, pp 89-99.

Schauder, S./Bassler, B.L. (2001) The languages of bacteria. In: Genes \& Development, Vol. 15, pp 1468-1480.

Schilmiller, A.L./Howe, G.A. (2005) Systemic signalling in the wound response. In: Current Opinion in Plant Biology, Vol. 8, pp 369377.

Schlicht, M./Strnad, M./Scanlon, M.J./Mancuso, S./Hochholdinger, F./Palme, K./Volkmann, D./Menzel, D./Baluska, F. (2006) Auxin immunolocalization implicates vesicular neurotransmitter-like mode of polar auxin transport in root apices. In: Plant Signaling \& Behaviour, Vol. 1, pp 122-33.

Schultz, J.C.IAppel, H.M. (2004) Cross-Kingdom Cross-Talk: Hormones shared by Plants and Their Insect Herbivores. In: Ecology, Vol. 85, pp 70-77. 
Schultze, K./Schimek, C./Wostemeyer, J./Burmester, A. (2005) Sexuality and parasitism share common regulatory pathways in the fungus Parasitella parasitica. In: Gene, Vol. 348, pp 33-44.

Schwarze, F.W./Engels, J./Mattheck, C. (2004) Fungal Strategies of Wood Decay in Trees. Second Edition, Heidelberg. Springer. Shackelton, L.A./Holmes, E.C. (2004) The evolution of large DNA viruses: combining genomic information of viruses and their hosts. In: Trends in Microbiology, Vol. 12, pp 458-465.

Shapiro, J.A. (1998) Thinking about Bacterial populations as multicellular Organisms. In: Annual Review of Microbiology, Vol. 52, pp 81-104.

Shapiro, J.A. (2007) Bacteria are small but not stupid: Cognition, natural genetic engineering and sociobacteriology. In: Studies in History and Philosophy of Biological and Biomedical Sciences. Vol. 38, pp 807-819

Sharma, A./Sahgal, M./Johri, B.N. (2003) Microbial communication in the rhizosphere: Operation of quorum sensing. In: Current Science, Vol. 85, pp 1164-1172.

Speriando, V./Torres, A.G./Jarvis, B./Nataro, J.P./Kaper J.B. (2003) Bacteria-host communication: the language of hormones. In: Proceedings of the National Academy of Sciences of the U S A, Vol. 100, pp 8951-8956.

Spoering, A.L./Gilmore, M.S. (2006) Quorum sensing and DNA release in bacterial biofilms. In: Current Opinion in Microbiology, Vol. 9, pp 133-137.

Srinivas, B.P./Hülskamp, M. (2005) Lessons from leaf epidermal patterning in plants. In: Fleming, A.J. (Ed.) Intercellular Communication in Plants. Annual Plant Reviews. Oxford. Blackwell Publishing, Vol. 16, pp 225-239.

Stanley, N.R./Lazazzera, B.A. (2004) Environmental signals and regulatory pathways that influence biofilm formation. In: Molecular Microbiology, Vol. 52, pp 917-924.

Strand, A. (2004) Plastid-to-nucleus signalling. In: Current Opinion in Plant Biology 7: 621-625.

Sullivan, B.T./Berisford, W.C. (2004) Semiochemicals From Fungal Associates of Bark Beetles May Mediate Host Location Behaviour of Parasitoids. In: Journal of Chemical Ecology, Vol. 30, pp 703-717.

Sun, J./Daniel, R./ Wagner-Dobler, I./Zeng A.P. (2004) Is autoinducer-2 a universal signal for interspecies communication: a comperative genomic and phylogenetic analysis of the synthesis and signal transduction pathways. In: BMC Evolutionary Biology, Vol. 4, p 36 .

Taga, M.E./Bassler, B.L. (2003) Chemical communication among bac-teria. Intercellular Communication in Plants. In: Proceedings of the National Academy of Sciences of the U S A, Vol. 100, pp 14549-14554.

Tassetto, M./Maizel, A./Osorio, J./Joliot, A. (2005) Plant and animal homeodomains use convergent mechanisms for intercellular transfer. In: EMBO Reports, Vol. 6, pp 885-890.

Tembrock, G. (1975) Biokommunikation. Informationsübertragung im biologischen Bereich. Wiesbaden. Vieweg Friedr. + Sohn Verlag.

Teplitski, M./Robinson, J.B./Bauer, W.D. (2000) Plants secrete substances that mimic bacterial $\mathrm{N}$ acylhomoserine lactone signal activities and affect population density dependent behaviours in associated bacteria. In: Molecular Plant Microbe Interactions, Vol. 13, pp 637-48.

Tettelin, H./Masignani, V./Ciesliwicz, M.J./Donati, C./Medini, D./Ward, N.L./Angiuoli, S.V./Crabtree, J./Jones, A.L./Durkin, S./Deboy, R.T./Davidson, T.M./Mora, M./Scarselli, M./Margarit, Y./Ros. I./Peterson, J.D./Hauser, C.R./Sundaram, J.P./Nelson, W.C./Madupu, R./Brinkac, L.M./Dodson, R.J./Rosovitz, M.J./Sullivan, S.A./Daugherty, S.C./Haft, D.H./Selengut, J./Gwinn, M.L./Zhou, L./Zafar, N./Khouri, H./Radune, D./Dimitrov, G./Watkins, K./O'Connor, K.B./Smith, D.L./Utterback, T.R./White, O./Rubens, C.E./Grandi, G./Madoff, L.C./Kasper, D./Telford, J./Wessels, M.R./Rappuoli, R./Fraser, C.M. (2005) Genome analysis of multiple pathogenic isolates of Streptococcus agalactiae: implications for the microbial "pan-genome". In: Proceedings of the National Academy of Sciences of the U S A, Vol. 102, pp 13950-13955.

Thomas, C.M./Nielsen, K.M. (2005) Mechanisms of, and barriers to, horizontal gene transfer between bacteria. In: Nature Reviews Microbiology, Vol. 3, pp 711-721.

Thompson, K.R./Olofsdotter, K./Chen, D.Y./Zhao, Y./O'Dell, T.J./Martin, K.C. (2004) Signalling from synapse to nucleus during longterm synaptic plasticity: a role for the classical active nuclear import pathway. In: Neuron, Vol. 44, pp 997-1009.

Thummel, C.S./Chory, J. (2002) Steroid signaling in plants and insects - common themes different pathways. In: Genes \& Development, Vol. 16, pp 3113-3129.

Torres, M.A./Dangl, J.L. (2005) Functions of respiratory burst oxidase in biotic interactions, abiotic stress and development. In: Current Opinion in Plant Biology, Vol. 8, pp 397-403.

Trewavas, A. (2003) Aspects of Plant Intelligence. In: Annals of Botany, Vol. 92, pp 1-20.

Trewavas, A. (2005) Green Plants as Intelligent Organisms. In: Trends in Plant Sciences, Vol. 10, pp 413-419.

Turkington, R./Sackville Hamilton, R./Gliddon, C. (1991) Within-population variation in localized and integrated responses of Trifolium repens to biotically patchy environments. In: Oecologia, Vol. 86, pp 183-192.

Vandenkoornhuyse, P./Baldauf, S.L./Leyval, C./Straczek, J./Young, P.J. (2002) Extensive fungal diversity in plant roots. In: Science, Vol. 295, p 2051.

Van Der Putten, W.H./Vet, L./Harvey, J.A./Wackers, F.L. (2001) Linking above- and belowground multitrophic interactions of plants, herbivores, pathogens, and their antagonists. In: Trends in Ecology and Evolution, Vol. 16, pp 547-554.

Van West, P./Morris, B.M./Reid, B. IAppiah, A.A./Osborne, M.C./Campbell, T.A./Shepherd, S.J./Gow, N.A.R. (2002) Oomycete plant pathogens use electric fields to target roots. In: Molecular Plant-Microbe Interactions, Vol. 15, pp 790-798.

Velicer, G.J. (2003) Social strife in the microbial world. In: Trends in Microbiology, Vol. 11, pp 330-337. 
Velicer, G.J./Kroos, L./Lenski, R.E. (2000) Developmental cheating in the social bacterium Myxococcus Xanthus. In: Nature, Vol. 404, pp 598-601.

Velicer, G.J./Yu, Y.T. (2003) Evolution and novel cooperative swarming in the bacterium Myxococcus Xanthus. In: Nature, Vol. 425, pp 75-78.

Villarreal, L.P. (2005) Viruses and the evolution of life. Washington. American Society for Microbiology Press.

Visick, K.L./Fuqua, C. (2005) Decoding Microbial Chatter: Cell-Cell Communication in Bacteria. In: Journal of Bacteriology, Vol. 187, pp 5507-5519.

Voloshin, S.A./Kaprelyants, A.S. (2004) Cell-cell interactions in bacterial populations. In: Biochemistry (mosc), Vol. 69, pp 12681275.

Wadhams, G.H./Armitage, J.P. (2004) Making sense of it all: bacterial chemotaxis. In: Nature Reviews Molecular Cell Biology, Vol. 5, pp 1024-1037.

Wang, L.H./He, Y./Gao, Y./Wu, J.E./Dong, Y.H./He, C./Wang, S.X./Weng, L.X./Xu, J.L./Tay, L./Fang, R.X./Zhang, L.H. (2004) A bacterial cell-cell communication signal with cross-kingdom structural analogues. In: Molecular Microbiology, Vol. 51, pp 903-912

Wang, M.B. Metzlaff, M. (2005) RNA silencing and antiviral defense in plants. In: Current Opinion of Plant Biology, Vol. 8, pp 216222.

Wang, P./Heitman, J. (1999) Signal transduction cascades regulating mating, filamentation and virulence in Cryptococcus neoformans. In: Current Opinion in Microbiology, Vol. 2, pp 358-362.

Walker, T.S./Bais, H.P./Grotewold, E./Vivanco, J.M. (2003) Root exudation and rhizosphere biology. In: Plant Physiology, Vol. 132, pp 44-51.

Weigl, D./Jürgens, G. (2005) Genetics. Hotheaded Healer. In: Nature, Vol. 434, p 443.

Witzany, G. (1993) Natur der Sprache - Sprache der Natur. Sprachpragmatische Philosophie der Biologie. Würzburg. Koenigshausen und Neumann.

Witzany, G. (1995) From the „logic of the molecular syntax“ to molecular pragmatism. In: Evolution and Cognition, Vol. 1, pp 148168.

Witzany, G. (1998) Explaining and understanding LIFE. In: Semiotica, Vol. 120, pp 421-438.

Witzany G. (2000) Life: The Communicative Structure. Norderstedt. Libri Books on Demand.

Witzany, G. (2002) Reduction of biological phenomena? Defictis of systems theory and the alternatives. In: W. Schmitz (Ed.) Sign Processes in Complex Systems. Berlin/New York. Mouton de Gruyter, pp 303-307.

Witzany, G. (2003) Metaphysics in Physics and Biology. In: Witzany, G. (2006) The Logos of the Bios 1, Helsinki. Umweb, pp 133140.

Witzany G. (2005a) Natural history of life: history of communication logics and dynamics. In: S.E.E.D. Journal, Vol. 5, pp 27-55.

Witzany, G. (2005b) From biosphere to semiosphere to social lifeworlds. Biology as an understanding social science. In: tripleC, Vol. 3, pp 51-74.

Witzany, G. (2006a) The Logos of the Bios 1. Contributions to the foundation of a three-leveled biosemiotics. Helsinki. Umweb. Witzany, G. (2006b) From Umwelt to Mitwelt. Natural laws versus rule-governed sign-mediated interactions. Semiotica 1: 425-438. Witzany, G. (2006c) Natural Genome Editing Competences of Viruses. In: Acta Biotheoretica, Vol. 54, pp 235-253.

Witzany, G. (2007a). Applied Biosemiotics: Fungal Communication. In: Witzany, G. (2007) (Ed.) Biosemiotics in Transdisciplinary Contexts. Proceedings of the Gathering in Biosemiotics 6, Salzburg 2006. Helsinki. Umweb, pp 295-301.

Witzany, G. (2007b). The Logos of the Bios 2. Bio-Communication. Helsinki. Umweb.

Woese, C.R./Kandler, O./Wheelis, M.L. (1990) Towards a natural system of organisms: Proposal for the domains Archaea, Bacteria and Eukarya. In: Proceedings of the National Academy of Sciences of the U S A, Vol 87, pp 4576-4579.

Wuertz, S. Okabe, S. Hausner, M. (2004) Microbial communities and their interactions in biofilm systems: an overview. In: Water Science Technology, Vol. 49, pp 327-336.

Wu, J. Glass, L.N. (2001) Identification of specificity determinants and generation of alleles with novel specificity at the het-c heterokaryon incompatibility locus of Neurospora crassa. In: Molecular Cell Biology, Vol. 21, pp 1045-1057.

Xia, Y. (2005) Peptides as signals. In: Fleming, A.J. (Ed.) Intercellular Communication in Plants. Annual Plant Reviews. Oxford. Blackwell Publishing, Vol. 16, pp 27-47.

Xie, G./Bonner, C.A./Song, J./Keyhani, N.O./Jensen, R.A. (2004) Inter-genomic displacement via lateral gene transfer of bacterial trp operons in an overall context of vertical genealogy. In: MBC Biology, Vol. 2, p 15.

Xonocostle-Cazares, B./Xiang, Y./Ruiz-Medrano, R./Wang, H./Monzer, J./Yoo, B.C./McFarland, KC./Franceschi, V.R./Lucas, W.J. (1999) Plant paralog to viral movement protein that potentiates transport of mRNA into the phloem. In: Science, Vol. 283, pp 9498.

Yoder, J.I. (1999) Parasitic plant responses to host plant signals: a model for subterranean plant-plant interactions. In: Current Opinion in Plant Biology, Vol. 2, pp 65-70.

Zimmermann, U./Schneider, H./Wegner, L.H./Haase, A. (2004) Water ascent in tall trees: does evolution of land plants rely on a highly metastable state? In: New Phytologist, Vol. 162, pp 575-615.

Zipfel, C.IFelix, G. (2005) Plants and animals: a different taste for microbes? In: Current Opinion in Plant Biology, Vol. 8, pp 353-360.

Zyalalov, A.A. (2004) Water flows in higher plants: physiology, evolution and system analysis. In: Russian Journal of Plant Physiology, Vol. 51, pp 547-555. 